\title{
Microstructural Analyses of a Giant Quartz Reef in South China reveal Episodic Brittle-Ductile Fluid Transfer
}

Lisa Tannock ${ }^{1 *}$, Marco Herwegh ${ }^{2}$, Alfons Berger ${ }^{2}, \mathrm{Jie} \mathrm{Liu}^{3}$, Pierre Lanari ${ }^{2}$, Klaus RegenauerLieb $^{1}$

${ }^{1}$ School of Minerals and Energy Resources Engineering, University of New South Wales, Sydney NSW 2052, Australia. 1.tannock@student.unsw.edu.au, Tel: (+61) 415990710 , klaus\&unsw.edu.au

${ }^{2}$ Institute of Geological Sciences, University of Bern, Switzerland. marco.herwegh@geo.unibe.ch, alfons.berger@geo.unibe.ch,pierre.lanari@geo.unibe.ch ${ }^{3}$ School of Earth Sciences and Engineering, Sun Yat-sen University, Guangzhou Guangdong. liujie86@mail.sysu.edu.cn

Keywords: Microstructures; Quartz veins; Geothermal; Shear zone evolution

\begin{abstract}
A long-lived hydrothermal system at the Heyuan fault, South China, has led to the development of a giant quartz reef, now partially exhumed along its length for more than $40 \mathrm{~km}$. Systematic analyses and focused microstructural studies have been undertaken to unravel a complex formation history of repeated fracturing, hydrothermal fluid flow and sealing cycles, resulting in a dynamic permeability across the fault zone. The change in morphology and decreasing grain-size with time further indicates the move from slow ductile opening to fast seismic events. Quartz reef formation has been estimated to occur within a range of $\sim 200-350^{\circ} \mathrm{C}$, based on evaluation of (i) quartz deformation microstructures; (ii) chlorite and mica geothermometry; and (iii) review of comparable quartz reef studies. Additionally, a set of physico-chemical formation conditions have been identified which compose the 'quartz reef window'. These are:
\end{abstract}


(i) significant volume of fluid; (ii) fluid sources from meteoric, metamorphic and/or from mantle origin; (iii) considerable Time-Integrated Fluid Fluxes; (iv) $\mathrm{SiO}_{2}$ oversaturation due to (a) temperature change, (b) sudden pressure drop, or (c) chemical change e.g. fluid mixing; (v) accommodation space to 'grow' the reef; (vi) channel permeability; and (vii) cap rock/seal to trap the fluid flow. The mechanism of quartz reef growth is here interpreted as the brittleductile analogue of the brittle fault-valve model.

\section{Introduction}

The purpose of this study is to perform a systematic analysis of the formation of a giant quartz reef to gain a deeper understanding of hydrothermal fluid transfer through the crust. The working hypothesis is that a quartz reef now exposed at the surface enables insights into processes that are happening at present day in the middle crust underneath active geothermal systems. The problems investigated in this study are the following: (1) Formation mechanisms of a giant quartz reef; (2) Time-evolution of the reef and fault permeability; (3) Understanding the micro-mechanisms of fluid transfer at the brittle ductile transition, as well as the implications of changes in micro-mechanisms for the present-day hot spring system.

Many giant quartz veins systems exist around the world that are investigated in particular for their role in epithermal mineral systems (Gandhi et al., 2000), or from a geodynamics point of view (Kerrich and Feng, 1992). However, there are only few known examples where the quartz reefs are exposed while the zone still features active geothermal surface manifestations. For example, the New Zealand epithermal gold-mineralization systems are active examples (Coromandel and Taupo Volcanic Zone), however, the exposed reefs are smaller in size or only inferred at depth. We chose the Heyuan fault active geothermal system as an ideal type locality for studying the exposed reef in the context of an intracontinental system and its hydrothermal 
activity at surface. The reef stretches along the fault for at least $40 \mathrm{~km}$, with an average $600 \mathrm{~m}$ outcrop width and a true thickness of at least $75 \mathrm{~m}$; Figures $1 \mathrm{~b}$ and 2). About $5 \mathrm{~km}^{2}$ are directly exposed owing to open pit mining activities. The quartz reef is defined here as the core of the Heyuan fault as it is surrounded by cataclasites on both sides and a mylonite zone in the uppermost part of its footwall (Figure 2).

The novelty of this paper is to exploit the context of the unique exposure of the reef itself with the geothermal implications from an analysis of the feeder system of present-day hot springs. We therefore investigate the Heyuan fault using a large-scale field mapping overview, which is the subject of Tannock et al. (submitted), while this study focuses on the mechano-structural evolution of the reef as derived from outcrop-scale structures in combination with microstructural analysis including a chemical characterization of the fault rocks and their hydrothermal interactions with the surrounding granites.

While the fault zone has been described in Chinese literature for its role in reservoir induced seismicity (Cheng et al., 2012; Qiu and Fenton, 2015) and its role in civil engineering structures, yet, no studies focusing on the geothermal and microstructural research are available. In the current study we close this gap by the approach presented before.

\section{Geological background}

The Heyuan Fault was formed, along with a series of NNE and ENE trending normal faults in the South China block, as a result of the late Mesozoic extensional regime (Ruoxin, Liu., et al., 1995). The series of adjoining and interacting faults striking NNE make up the larger $\sim 700$ kilometre Shaowu-Heyuan Fault zone (Lee et al., 1997). The secondary normal faults aligned parallel with the Heyuan fault generally exhibit higher dip angles $\left(>60-70^{\circ}\right)$ (Ding, 1989), 
compared to the Heyuan fault; which varies laterally along its length, dipping between $\sim 25$ $55^{\circ}$ towards to the SE. These faults cut through a Proterozoic to Silurian basement, folded and metamorphosed during the early Paleozoic orogenic event. These rocks were subsequently folded during the Indosian and Yanshannian orogenies, following a period of sedimentation, which coincided with significant granitic intrusion in the latter, taking place in the Mesozoic (Wan, 2012). The Heyuan fault cuts through one of these large granite intrusions, termed the Xinfengjiang pluton, which is an extension of the larger Fogang batholith to the west of the fault (Chen and Talwani, 1998; Qiu and Fenton, 2015).

Several basins, scarps and hot springs have resulted from movement along the fault zone during the Mesozoic to Cenozoic (Wang et al., 2014). These hot springs continue to present day along the Heyuan fault zone, with surface temperatures ranging from $24-76^{\circ} \mathrm{C}$. As a result of precipitation from the hydrothermal fluid flow supplying the hot springs since the Mesozoic, a giant quartz reef body has formed in the core of the Heyuan fault. Due to subsequent exhumation, large exposures (up to tens of meters thick) of the quartz reef outcrop locally along the length of the fault (Figure 1b).

The stress regime in the South China Block changed from extensional in the Mesozoic due to paleo-Pacific plate subduction and rollback beneath the eastern Asian continent ( $\mathrm{Li}$ and $\mathrm{Li}$, 2007; Zhou et al., 2006), to compressional in the Cenozoic thought to be as a result of EurasiaIndia subduction and collision which became the more dominant effect (Tang et al., 2014). This led to the creation and subsequent reactivation of strike-slip faults cross-cutting the Heyuan faults, trending WNW and NNW. The Shijiao-Xingang-Baitian fault being the largest identified NNW striking fault cross-cutting the Heyuan fault (Figure 1); it is active in the present-day stress field, and has shown increased seismicity, particularly at the intersection of 
the Heyuan fault, since the 1960's as a result of reservoir-induced seismicity (Cheng et al., 2012; Qiu and Fenton, 2015).

\section{Methods}

\subsection{Macro-scale}

Macro-scale information is obtained via a combination of geological field work and sampling, lineament analysis from remote sensing imagery and photogrammetry fracture analysis. Building on the macro-scale framework and geometrical cross cutting relationships, microscale methods, as detailed below, were employed in interrogate the processes and mechanisms operating in the Heyuan geothermal fault system over time.

\subsection{Microstructures, Precipitation \& Deformation mechanisms (SEM)}

Initial observations and characterisation were performed using a transmitted light microscope. More detailed investigation was then carried out performing Scanning Electron Microscopy (SEM; Zeiss EVO 50 at University of Bern) using a beam current of $20 \mathrm{keV}$, for higher resolution investigations on the microstructures. Energy Dispersive X-Ray Spectroscopy (EDS) data are collected using TEAM software (EDAX) in combination with $\varphi \rho Z$ corrections. In order to show local average composition, beam scans in the range of $0.2-1 \mathrm{~mm}^{2}$ are done using counting times between 100 and $500 \mathrm{~s}$. Quality of such local area measurements are controlled by multiple measurements of the same structure. Compositions of such areas are given as an average value with deviation derived from such multiple measurements.

Signals employed on the SEM include: Backscattered Electrons (BSE) to provide contrast between different mineral grains and intracrystalline compositional variations; as well as 
Variable Pressure Secondary Electrons (VPSE) which are used to detect mainly the CL signal of the quartz grains.

\subsection{Electron Microprobe}

Following transmitted light microscopy, identified white mica in the mylonite and quartz reef samples were located and marked for analysis under the Electron Probe Micro-Analyzer (EPMA; JEOL superprobe JXA8200) to quantify mineral compositions $\left(\mathrm{SiO}_{2}, \mathrm{TiO}_{2}, \mathrm{Al}_{2} \mathrm{O}_{3}\right.$, $\mathrm{FeO}, \mathrm{MnO}, \mathrm{MgO}, \mathrm{CaO}, \mathrm{Na}_{2} \mathrm{O}, \mathrm{K}_{2} \mathrm{O}$ ). EPMA settings used were $15 \mathrm{keV}$ acceleration voltage, $10 \mathrm{nA}$ beam current and a $3 \mu \mathrm{m}$ beam size to avoid diffusion in the grains. Natural and synthetic silicate standards were used for calibration. The results are grouped and average compositions are used. Structural formulae calculations were done on a basis of 11 and 14 atoms of oxygen for K-white mica and chlorite, respectively. Several calibrations have been developed (e.g. Vidal et al. 2006; Lanari et al. 2014) and the most recent of them are used in this study: Chlorite + Quartz + Water (Vidal et al., 2016) and Phengite + Quartz + Water (Dubacq et al., 2010); which have been shown as a robust method to calculate temperatures over a range of $25-800^{\circ} \mathrm{C}$ and up to $5 \mathrm{GPa}$ for white mica (Dubacq et al., 2010), and up to $500^{\circ} \mathrm{C}$ and $18 \mathrm{kbar}$ for chlorite (Lanari et al., 2014b; Vidal et al., 2016). A comprehensive description of this technique based on the progressive hydration of the vacancies along a P-T divariant equilibrium curve is provided together with application examples in Lanari et al. (2012). Computations were achieved using the in-house program ChlMicaEqui (Lanari, 2012). The uncertainties on the P$\mathrm{T}$ calculations from these geothermometry methods are approximately $\pm 2 \mathrm{kbar}$ and $\pm 50^{\circ} \mathrm{C}$ (Lanari et al., 2014b, 2014a; Vidal et al., 2016). While the chlorite geothermometer is a practical tool across a range of chlorite compositions and geological environments (Lanari et al., 2014b), it depends on the availability, and the ability to distinguish between detrital and hydrothermal chlorite, of which the latter is required. This can be further problematic when 
grain-size is very small. In this study, chlorite was found in several samples, however it could only be confirmed as hydrothermal a subset of these, of which testing was performed.

These geothermometry methods were selected due to i) being most suitable for the mineral constituents present (chlorite and phengite); ii) being widely accepted, established and robust methods (e.g. Berger et al., 2017; Ferrero et al., 2019; Inoue et al., 2018; Lanari et al., 2014a and references therein); iii) the P-T limitations being within the expected range; and iv) the alternative method of fluid inclusion studies was outside the resources available to the project.

\subsection{Grain size}

Grain sizes were measured directly on SEM to identify the smallest grain sizes in samples, which have a micro-crystalline matrix. The range of grain sizes across each sample was obtained via transmitted light microscopy and a "Mosaic image analyser" (MIA) stage on an Olympus BX-51 microscope in order to provide an overview comparison of samples side-byside on a larger field of view. Sampling spots were located across each sample to include characterisation of any micro-facies affecting the grain size distribution. The diameter of several grains were measured in each spot location of each sample. Additionally, ImageJ 1.51 (e.g., Schneider et al. 2012) was used to characterise the grain sizes across the microphotographs under cross polarised light at two different magnifications ( $\mathrm{x} 40$ and $\mathrm{x} 100)$ in order to capture both larger grain sizes and the finer matrix particles. This was achieved by colour thresholding the images to highlight lighter coloured grains, and fitting ellipses to provide a major axis measurement estimate equivalent to the maximum grain diameter. For the distribution analysis, grains $<4 \mu \mathrm{m}$ were discounted to ensure there were at least 3-5 pixels composing the smallest grains. Pixels sizes in the analysed images were $1.6 \mu \mathrm{m}$ for the $\mathrm{x} 40$ magnification micrographs, and $0.6 \mu \mathrm{m}$ for the $\mathrm{x} 100$ micrographs. While this provided greater 
volume of data and avoided selection bias, the error margin is likely larger due to the poor distinction between quartz grains.

3.5. Identification of vein and fracture generations across the facies

The term 'facies' is used here to refer to the different structural units which compose the fault zone (transitioning from the granite, mylonite, cataclasites and quartz reef on the footwall and hanging wall of the fault). In order to decode the fracture and veining generations of throughout the fault zone, the following factors were used to identify each generation, and link them together with corresponding generations in across the facies:

- Composition of mineral infill

- Grain size of mineral infill

- Fracture mode (mode I, II-III)

- Dip angle and azimuth (\& discordance relative to the host fabric)

- Abundance/frequency

- Relative age sequence based on cross-cutting relationships

\section{Field relations}

The Heyuan fault zone is composed of several structural facies which are exposed via a roadcut at route $205\left(23^{\circ} 59^{\prime} 12^{\prime \prime} \mathrm{N} 115^{\circ} 02^{\prime} 05^{\prime \prime} \mathrm{E}\right)$, and quarry sites including the Xinfeng granite quarry $\left(24^{\circ} 00^{\prime} 35^{\prime \prime} \mathrm{N} 115^{\circ} 03^{\prime} 50^{\prime \prime} \mathrm{E}\right)$ and Leiyao quartz mine site $\left(24^{\circ} 00^{\prime} 56^{\prime \prime} \mathrm{N} 115^{\circ} 04^{\prime} 45^{\prime \prime} \mathrm{E}\right)$ being representative for the footwall host granite and the quartz reef, respectively (Figure 1). 


\section{Macro to Microstructures}

The following section provides an overview and description of the various facies and fault rocks encountered across the cross-section transect, from the macro- (outcrop) through meso(hand sample) (Figures 3 and 4) to focus on the microscale (Figures 5 and 6); from the distal end of the hanging wall through to the footwall host rock.

\subsection{Footwall and hanging wall host granites}

The host rock of the Heyuan fault is a late Jurassic Yashanianian biotite-granite ( 35 vol.\% quartz, $\sim 30$ vol.\% plagioclase, $\sim 30$ vol. $\%$ K-feldspar, $\sim 5$ vol. $\%$ biotite), with magmatic biotite altering to chlorite. Feldspars are altered and particularly the K-feldspar has undergone heavy sericitisation in the footwall.

The initial grain sizes in the undeformed host granite range from 1-8 $\mathrm{mm}$, being slightly inequigranular (sample HY17-1, Figure 1, Table 1). With increasing proximity towards the fault zone, the grain size becomes increasingly more equigranular (HY17-5), as the grain size distribution changes to fine-medium grained $(0.3-4 \mathrm{~mm})$, with a high proportion of broken grains and fractures through the rock.

\subsection{Granite Mylonite}

Several bands of mylonite are present transitioning across the footwall in the fault zone (Figures 2 and 3). These mylonite bands, up to $20 \mathrm{~m}$ thick, dip $\sim 46^{\circ} / 148^{\circ}$ southeast, with narrower connecting branches, up to $1 \mathrm{~m}$ wide, dipping more shallowly $\sim 15^{\circ} / 137^{\circ} \mathrm{SE}$. Stretching lineations on average plunge $\sim 16^{\circ} / 130^{\circ}$ SE. The lenses of intact granite show a 
general decrease in spacing approaching the fault plane with mylonitic bands at $215 \mathrm{~m}, 200 \mathrm{~m}$, 120-100 $\mathrm{m}$, and $70 \mathrm{~m}$ from the fault plane.

Chemically, the mylonite represents mineralogy from its granitic host with all the same mineral constituents present. However, with increasing proximity to the fault core there is a gradual increase in frequency of quartz veining. Selected area EDS analysis was performed to obtain the composition of the matrix on the SEM to avoid inclusion of quartz veinlets. From this, normative mineralogy (Kelsey, 1965) showed that the composition of the mylonite varied $\sim 8$ 20 vol.\% lower in quartz relative to the host granite, while K-feldspar varied across mylonite samples $+/-15$ vol. $\%$ relative to the granite.

Three mylonite samples were collected from different locations in the footwall (HY17-21, HY17-8 and HY17-18 moving towards the quartz reef fault core, see Table 1). The very finegrained ultramylonite $(5-20 \mu \mathrm{m})$ with grain sizes $<10 \%$ of their original size in the granite, is polymineralic and exhibits multiple viscous granular flow events which can be discriminated from one another as the foliation angle changes slightly with each event, providing crossfoliated structures (Figure 3e). Subsequent cataclastic overprinting and numerous veining events have occurred throughout the samples underlining the repetitive nature of deformation. The general aspects of viscous deformation can be found in the sample series towards the quartz reef (samples HY17-21, HY17-8, HY17-18). This is expressed by decreasing number and size of microlithons and stronger planar fabrics towards the fault core. The quartz shows different degrees of dynamic recrystallisation, which is dominated by bulging recrystallisation (BLG) and locally subgrain rotation recystallisation (SGR; Stipp et al. 2002a; Haertel \& Herwegh 2014). The general trend of less cataclastic overprint toward the fault core accompanies the ductile microstructures. 
Repeated cycles of crack-seal deformation are particularly evident from sample HY17-8 (the more distal mylonite zone). Existing veins having been exploited and refractured, for example, where iron oxide trails have been precipitated down the centre of a quartz vein due to secondary refracturing and fluid flow. The crack-seal mechanism occurs through repeated mode-I tensile fracturing and subsequent precipitation of quartz out of the hydrothermal fluid (Ramsay, 1980). Similarly, 'crack-seal, slip' deformation has been observed in sample HY17-18 (Figure 5g-i). , which is differentiated by a secondary reactivation of the vein by a shear displacement. This process has been described for calcite-filled veins exhibiting the same branching and widening micro-structure seen here, which are attributed to be reactivated due to strike-slip faults (Petit et al., 1999).

In all of the mylonite samples analysed the mylonitic fabric is overprinted by brittle quartz vein formation, followed by subsequent mylonitisation events which have ductiley deformed the quartz veins in the matrix. These veins are then further overprinted by later generations of brittle quartz veining (Figure 3e).

\subsection{Quartz-adularia cataclasite (footwall)}

A zone of fine-grained, highly altered and locally fissile, buff coloured tectonite covers an area $\sim 75 \mathrm{~m}$ in width between the mylonitised granite and the quartz reef (Figure 4). The contact between these units is not clearly defined and transitions as a progression of increasing abundance of quartz veins and cataclasis, while the amount of un- to weakly deformed host rock decreases. Large idiomorphic quartz crystals up to $5 \mathrm{~cm}$ long, orientated in the direction of opening, can be found within several of these larger veins, exhibiting slight to moderate subsequent brittle deformation. The cataclasite is composed of quartz ( $\sim 80-85$ vol.\%) and 
adularia; with both minerals of hydrothermal origin. Angular lath shaped clasts, up to 20 $30 \mathrm{~mm}$ in diameter, composed of broken fragments of quartz crystals of remnant veins are found periodically in zones across the cataclasite, composing approximately $5-10$ vol.\% proportion of the rock (Figures $4 \mathrm{f}$ and $4 \mathrm{~g}$ ).

Grain sizes of the cataclasite matrix range from $4-585 \mu \mathrm{m}$, with a mean of $7 \mu \mathrm{m}$. Note that the larger crystals were outside the maximum field of view for this analysis, with a grain size diameter ranging between $\sim 1-10 \mathrm{~mm}$. Grain shapes are angular, broken and/or with evidence of neo-crystallisation rims (Figure 5). Locally, a bimodal fabric of elongate quartz grains (typically $\sim 280 \mu \mathrm{m}$ major axis by $<30 \mu \mathrm{m}$ minor axis) has been produced, which appears to be the result of crack-seal processes as no apparent shear offset can be seen, producing conjugate fracture sets enclosing angles $<80^{\circ}$. The average dip of the fractures sets is $\sim 47^{\circ}$ and $\sim 40^{\circ}$, respectively (Figure 6g).

Localised occurrences of quartz grains exhibiting lobate boundaries and bulging (BLG) recrystallisation were present towards the contact with the quartz reef (Figure 6), but were absent elsewhere in the unit, indicating temperatures did not likely far exceed $300^{\circ} \mathrm{C}$.

\subsection{Quartz-sericite ultracataclasite/phyllonite (hanging wall)}

A similar tectonite, composed primarily of quartz is located on the hanging wall of the fault, immediately above the quartz reef. This zone has a width of $\sim 25 \mathrm{~m}$. The Cretaceous sedimentary "Red beds" of the Heyuan river basin are situated to the southeast, with the contact between these units hidden. A possible gouge layer may also exist between these units but is completely hidden because of intense vegetation cover. 
The main differentiating features between the tectonite observed in the hanging wall compared to the footwall are (i) the high abundance of white mica, (ii) a much finer grain size, and (iii) a foliated matrix. The hanging wall tectonite can therefore be termed a 'quartz-sericite ultracataclasite' or phyllonite, while the footwall unit represents a 'quartz-adularia cataclasite'.

The matrix of the hanging wall facies has a finer grain size, ranging from 4-272 $\mu \mathrm{m}$ (mean $\sim 5 \mu \mathrm{m}$ ) than the footwall unit (mean $\sim 7 \mu \mathrm{m}$ ), and individual grains are hard to distinguish, though sericite mica is obvious and abundant. The foliated fabric of the ultracataclasite displays fine anastomosing bands, around larger (300 $\mu \mathrm{m}-4 \mathrm{~mm}$ diameter) remnant clasts of quartz. The latter exhibit undulose extinction, and locally lobate boundaries indicating low temperature plasticity, while quartz veins remain at various stages of brittle deformation to no deformation (Figure 5).

Both the footwall and the hanging wall cataclasites represent brittle deformation at the margins of the quartz reef, and exhibit compaction in the form of dissolution seams and precipitation of quartz overgrowth into pore space, as well as localised deformation structures, e.g. BLG (Figure 6).

\subsection{Fractures and veins}

Several generations of veining are present, within increasing frequency from the host granite footwall towards the fault zone (Figure 3). These vein generations are observed to overprint one another with the relative timing, from oldest to youngest, described based on their primary composition, include: (i) chlorite, (ii) epidote, (iii) multiple quartz generations, and (iv) haematite (Figure 3). A marked change in the vein-composition occurs in the cataclasite and quartz reef facies e.g. early chlorite and epidote veins observed in the granite and mylonite, are 
absent from the hydrothermal units. The combination of those observations led to the following vein and veinlet groups as shown in Table 2.

\section{The Quartz Reef}

The quartz reef effectively forms the 'core' of the fault zone. As mentioned above, there is a gradual transition from the footwall cataclasite unit into the quartz reef. We define the boundary in outcrops where more than 70 vol.\% of quartz veins are present. In the case of the drill core samples, the transition occurs over a distance of less than 4.2 meters, i.e., between depths of $57.6 \mathrm{~m}$ (quartz reef) and $61.8 \mathrm{~m}$ (tectonite) drilled from a surface elevation of $145 \mathrm{~m}$ in the Leiyao quartz quarry (Figure 2, Table 1). While there is still a high degree of internal complexity, with brittle fracturing and precipitation recrystallisation processes apparent in the quartz reef, there is a clear distinction between the quartz reef and the cataclasite. (Figure 4). The composition of the reef is significantly higher in quartz ( $>97 \mathrm{vol.} \%$, compared to $<85$ vol. $\%$ in the cataclasite), and still has subidiomorphic to idiomorphic quartz crystals with intermediate to coarse grain-sizes. The quartz reef is dipping $30-46^{\circ} / 122^{\circ}$ to the southeast in the study area. The apparent width measured to be $\sim 200 \mathrm{~m}$, and a true thickness calculated as at least $\sim 75 \mathrm{~m}$.

Core samples were taken through the quartz reef from $2.6 \mathrm{~m}$ to $61.8 \mathrm{~m}$ where it reached the footwall cataclasite. From a depth of $48.95 \mathrm{~m}$ into the quartz reef the first signs of pressure solution begin, which is visible in sutured grain contacts (Figure 6). With further increasing depth, deformation lamellae is observed in the quartz grains, followed by lobate boundaries which appear locally towards the quartz reef-cataclasite footwall boundary (the contact between the two units however, is not directly observed due to incomplete drill core sample) . 


\subsection{Structural processes in the quartz reef}

Prior to the formation the quartz reef, we have no direct evidence on the timing of the structural facies (mylonite, hydrothermal cataclasite etc.). Only from the presence/absence of different vein generations in these units can we infer the relative timing of events (Table 2). However, post-nucleation of the early quartz reef, a clear sequence of fracturing events can be identified.

Multiple phases of fracturing, healing, cataclasis and neo-crystallisation growth have been observed inside the quartz reef, which all contribute to the formation of the reef. Below are described the five key structural processes observed within the quartz reef, which appear to have a close correlation with grain-size: i) mode-I opening and ii) neo-crystallisation growth, both operating as a response to precipitation out of a hydrothermal fluid following fracturing; iii) growth which appears limited as a result of interaction with other minerals i.e. mica; iv) controlled, incremental fracturing and growth; and v) shear fracture abrasion without quartz precipitation (Figure 7).

\subsubsection{Mode-I Void Opening (hydrothermal growth)}

The earliest generations of fracturing within the quartz reef samples exhibit the coarsest grain sizes (on average $>1-10 \mathrm{~mm}$ ) in well-developed idiomorphic crystals (Figure 7a), resulting from either slower fracture opening or longer-term opening compared to the subsequently generated finer-grained quartz.

6.1.2. Neo-crystallisation (hydrothermal growth) on cataclastic material

Neo-crystallised quartz grains are evident in localised patches and pore spaces. In VPSE imaging the old broken cores of the quartz cataclasite grains can be distinguished from the 
hydrothermal growth rims (Figure $7 \mathrm{~b}$, inset). Key evidence are fillings of neo-crystallised quartz (the recrystalized grains) with intermediate grain sizes $\sim 40-300 \mu \mathrm{m}$ (mean $100 \mu \mathrm{m}$ ), situated between coarser, usually well-developed crystals (Figure 7b).

\subsubsection{Mica "pinning" (restricted growth)}

Locally, there is a correlation between decreased (or inhibited) quartz grain-size and the presence of white mica. Hydrothermal quartz growth appears restricted or "pinned" where mica borders the grains (Figure 7c). This mechanism of pinning by a secondary phase at grain boundaries, is a well explored process limiting grain coarsening in polymineralic solid material (Evans et al., 2001; Herwegh et al., 2011). It has been shown that from this process, increased mica content correlates with a decreasing average quartz grain-size (Song and Ree, 2007). Indirect evidence of mica pinning is shown by patches of intermediate-fine grained quartz "pinned" by mica platelets that are adjacent to larger grain-sized quartz in the absence of mica (Figure 7c). Quartz growth rims can be seen locally enclosing previous detrital quartz, indicating a nucleation-controlled precipitation (Hillig, 1966) from the fluid in newly generated cavities. In the studied samples, the presence of mica correlates with an average quartz grainsize $\sim 40 \%$ smaller ( $\sim 20-180 \mu \mathrm{m}$, mean $45 \mu \mathrm{m}$, in comparison to the neo-crystallisation growth generally absent of mica $(\sim 20-1135 \mu \mathrm{m}$, mean $72 \mu \mathrm{m})$. An alternative interpretation of these observations is that the fine-grained quartz is a product of localised cataclasis with interrelated fluid flow of mica-bearing fluid flow.

\subsubsection{Incremental Fracture Opening (controlled hydrothermal growth)}

Fine-grained quartz is observed within fractures, forming a clear contrast to the larger grained quartz through which the fracture occurred. Such fractures are often accompanied by narrower 
veins on either side, giving a progressive banding appearance (Figure 7d). The grain sizes observed ranged from $\sim 10-120 \mu \mathrm{m}$ (mean $35 \mu \mathrm{m}$ ). The quartz grains within these veins show evidence of recrystallisation of brittle fractured material, in the form of growth rims seen in VPSE mode (Figure 7d, right side). Note the observation of mode-I opening with some grains growth perpendicular to the vein opening direction. This behaviour can be attributed to crackseal mechanisms (Ramsay, 1980) with fragmentation potentially resulting from minor shear slip processes as repeated events trigger increasing number of bands develop (Petit et al., 1999).

\subsubsection{Shear Fracture Abrasion (fractured)}

Shear fractures creating small $(<\mathrm{mm})$ offsets and dilatational jogs are observed, containing deposits of ultrafine quartz material. Key evidence for a brittle deformation origin is the presence of ground ultrafine, detrital angular quartz fragments $(<5-40 \mu \mathrm{m}$, mean, $11 \mu \mathrm{m}$ diameter), either deposited along a fracture plane or in a pore space (Figure 7e). Open porosity remains along the fracture planes and in pore space where the detrital grains do not fill. Subsequent hydrothermal growth may occur on grains, but there is little evidence of it here as it is a late stage event, given by the fact that these fractures crosscut all other features. This latest event can be related to the sub-vertical fracturing seen on the outcrop scale, which are also largely unmineralized. Therefore, providing permeable pathways for present-day fluid flow.

\subsubsection{Spatial variation of hydrothermal growth and fracturing in the quartz reef}

As the grain size in the quartz reef is closely correlated to the formation mechanism (hydrothermal growth preserved, or mode of fracturing) as described above, the spatial variation in grain-size can give an indication on the distribution of these mechanisms. Aforementioned drill core through the reef provides a vertical transect to illustrate this. 
With increasing depth through the quartz reef, there are some variations between dominant growth versus fracture mechanisms (Table 3). Overall it appears that the distribution of mechanisms and related grain-size formation are homogeneously distributed throughout the quartz reef, with the exception of the most recent generation (shear fracture abrasion), which was observed only in the shallower depths. However, this is the only such material that was observed to not have subsequent hydrothermal growth on the grains, and therefore, these may be present at deeper levels and undergone recrystallised growth (such as described above as 'neo-crystallisation').

\section{Mineral chemistry and temperature estimates}

\subsection{Mica geothermometry}

Despite the high variations in microstructures, the quartz reef contains more than $97 \mathrm{vol} . \%$ quartz. Other common minerals in the quartz reef are micas (Table 4), Fe and Cr oxides, and

sulfides (Table 5). The transition to the footwall cataclasite (see section 5.3) contains additional Ti-oxides, zircon, monazite and apatite. In addition to the already described difference of the microstructures the occurrence of these minerals indicate a different origin as the quartz reef samples sensu stricto, which are lacking minerals like monazite and zircon. These observations indicate the dominant transport of $\mathrm{SiO}_{2}$ in the fluid with some proportions of $\mathrm{Al}, \mathrm{K}$ and transition metals $(\mathrm{Fe}, \mathrm{Cr}$ ) leading to precipitation of quartz and the above-mentioned sheetsilicates. In the following, the sheet silicates will be explored in terms of their major chemical compositions.

White mica were measured in four samples from the drill core (Table 3). The white mica are assumed to have grown in equilibrium with quartz and water. This assumption is reasonable for hydrothermal systems and is largely supported by the absence of compositional zoning and re-equilibration features (e.g. Airaghi et al., 2017 for white mica partially re-equilibrated by 
interaction with fluids). It is common to phyllosilicates to preserve equilibrium conditions with quartz and water in hydrothermal systems (Cantarero et al., 2014; Trincal et al., 2015).

The paragonite component in these micas is very low (close to the detection limit of the EMP). The different samples are indistinguishable in terms of those mica compositions, which can be described as muscovite/phengite (Figure 8). However, at several places significant amounts of $\mathrm{Cr}$ are incorporated into such micas; these grains will be excluded from the following investigations.

The mica geothermometry 'Phengite + Quartz + Water' (Dubacq et al., 2010), (described in methods section 3.3) resulted in temperatures of $\sim 370^{\circ} \mathrm{C}$ assuming $2 \mathrm{kbar}$, based on a brittleductile transition at around $7.5 \mathrm{~km}$ depth for a granitic crust, in which quartz veins have been typically observed to develop in this zone between 2-3 kbar (Bons, 2001; Kerrich and Feng, 1992; Sibson, 1989; Sibson et al., 1988), (Table 5, Figure 9). Individual samples show temperatures between 350 and $390^{\circ} \mathrm{C}$, but all samples are indistinguishable from each other within the obtained error range. Due to pressure dependency of the Tschermak exchange in micas, the temperatures would be $10-15^{\circ}$ higher assuming an equilibration pressure at $4 \mathrm{kbar}$. These calculations use a water activity of 1 .

\subsection{Chlorite geothermometry}

The mylonites are characterized by newly developed chlorite and white mica in addition to the above described veins and veinlets, which are of purely hydrothermal origin. The white micas are very rare and their compositions overlap with the muscovite/phengite described in the last section (section 7.1, Figure 8). The chlorite can be distinguished into (i) local replacement structures (most likely from biotite) and (ii) newly nucleating grains in new voids 
(hydrothermal origin). This is also indicated by the large spread of compositions in such chlorites. Selecting the newly developed chlorite composition, temperature estimates generated using the thermometer 'Chlorite + Quartz + Water' (Vidal et al., 2016) were $\sim 287^{\circ} \mathrm{C}$ Sample 1 and $265^{\circ} \mathrm{C}$ sample 21 ; which are lower than those obtained from the white mica $\left(\sim 330^{\circ} \mathrm{C}\right.$ Sample 21), Table 5.

\subsection{Temperature estimates from dynamic recrystallisation microstructures}

Due to the manner in which quartz recrystallises at known P-T conditions under a common range of strain rates for shear zones $\left(\sim 200 \mathrm{MPa}\right.$ and $10^{-11}$ to $\left.10^{-14} \mathrm{~s}^{-1}\right)$ (Stipp et al., 2002b), identification of dynamic recrystallisation microstructures, namely (i) bulging recrystallisation; (ii) subgrain rotation recystallisation and (iii) grain boundary migration recrystallization, can be used to give a first-pass temperature range evolution (Guillope \& Poirier 1979; Stipp et al. 2002a; Stipp et al. 2002b; Haertel and Herwegh 2014). This indicative, structural thermometric interpretation is contrasted here to the more robust mica and chlorite thermometry.

Bulging recrystallisation (BLG) was observed in several places within the mylonite, while in the footwall cataclasite it is only locally observed towards the contact with the quartz reef, at the base of the core drilled from Leiyao mine site (sample Q1-61.8). These BLG structures develop in the temperature range $280-400^{\circ} \mathrm{C}$ (Stipp et al. 2002a; Stipp et al. 2002b; Haertel and Herwegh 2014).

Aside from that, the cataclasites exhibited frictional granular flow (Figure 5d), keeping the deformation below the frictional-viscous transition (Handy et al., 2007; Schmid and Handy, 1991), which is reported to be around $\sim 280^{\circ} \mathrm{C}$ across a common range of widely observed shear zones (strain rates between $10^{-14} \mathrm{~s}^{-1}$ and $10^{-11} \mathrm{~s}^{-1}$ ) (Stipp et al. 2002b). Therefore, it is most likely 
that footwall cataclasite development occurred above, but did not greatly exceed, this temperature. Whilst the hanging wall cataclasite-phyllonite (in the absence of any dynamic quartz recystallisation structures observed) formed somewhat cooler than this.

Subgrain rotation recystallisation (SGR) was observed locally within deformed quartz veins in the mylonite (sample HY17-18, Figure 6), which according to the structural interpretation of temperature dependant quartz mechanisms by Stipp et al. (2002a and 2002b), yields a deformation temperature window of between $350-500^{\circ} \mathrm{C}$. As these microstructures were observed locally, and in one mylonite sample location (closest to the fault core) only, the temperature experienced was probably closest to the lower end of this range.

Through the quartz reef there is an increase in low-temperature plasticity with depth such as deformation lamellae (Figure 6), however, there is no evidence of any pervasive crystalplastic deformation.

\section{Volume estimates and possible fluid sources}

The volumetric strain can be estimated based on the width change across the mylonite and cataclasite, with the following assumptions: (i) ii) solute generation by dissolutionprecipitation reaction; (ii) solute removal from the host granite (no external sources); (iii) planar geometry; precipitation reaction; (iv) mass removal assessed by a line perpendicular the planar geometry. Under these assumptions, the volume change can be assessed on a 1-D crosssection (The volumetric strain ' $\mathcal{E} v$ ' is given by the change in volume ' $\delta V$ ' over the original volume ' $V$ ': 


$$
\varepsilon v=\delta V / V
$$

\section{Footwall}

Minor cataclasis of the granite is present at the top of the footwall of $\sim 5 \mathrm{~m}$ thickness. We exclude this layer from out volume estimates as it is a minor constituent and no indicators of mass flow are available.

Below the cataclasite, the volumetric strain of the mylonite can however be estimated based on the ratio of veins (syn-to post kinematically emplaced) with the host material. This equates to $<20 \%$ volumetric strain, based on $\sim 20$ vol. $\%$ veins across the mylonite zone of $\sim 150 \mathrm{~m}$. The inherent assumption in this estimate is that the volume of the quartz removed from the mylonite stays within the mylonite as quartz veins. This is clearly a lower-bound estimate of zero fluid flow into the quartz reef.

Assuming the cataclasites on both sides of the quartz reef were formed almost entirely from hydrothermal material they are excluded from this analysis and attributed to the quartz reef.

\section{Hanging Wall}

We are using detailed analysis of the chemical reactions for a phyllonite formation in the Appalachians from O'Hara, (1988) as an order of magnitude estimate for the volumetric strain in the hanging wall. O'Hara, (1988) estimated a minimum volume loss of $60 \%$ through feldspar dissolution of the host granite to form phyllonite, through the following main reaction:

$$
3 \text { KFeldspar }+2 \mathrm{H}^{+} \rightleftharpoons \text { Muscovite }+2 \mathrm{~K}^{+}+6 \mathrm{SiO}_{2} \text { (aqueous) }
$$


Similar to O'Hara, (1988), the ultracataclasite/phyllonite in the hanging wall, has formed from K-feldspar dissolution. Assuming all of the aqueous quartz from the phyllonitic reaction (equation 2) contributes to the formation of the quartz reef we can estimate the upper bound mass flux from the phyllonitic cap for the formation of the quartz reef. The current thickness of the phyllonitic cap is at least $25 \mathrm{~m}$ (as measured in the field) and a $60 \%$ volumetric strain would equate to a $62.5 \mathrm{~m}$ thickness of the original undeformed protolith. This would contribute a minimum of $37.5 \mathrm{~m}$ thickness to the quartz reef.

\section{The Quartz Reef and its Cataclasite}

The thickness of the quartz reef as measured in the field is at least $75 \mathrm{~m}$. Underlying the quartz reef is a cataclasite of similar thickness, of hydrothermal origin. The combined thickness of at least $150 \mathrm{~m}$ requires significant volume flux which can either be sourced from the hanging wall, the footwall, or an external source. The above described volumetric strain estimates suggest the neither the footwall nor the hanging wall can supply sufficient mass to build a quartz reef, and it is postulated here that an outside fluid source is required.

\section{Discussion}

Due to the unique exposure of the Heyuan fault quartz reef we have been able to describe fluid transfer processes in the middle crust from the micro-scale observations. The current contribution focuses on the microstructural observation in relation to the formation of the quartz reef, while the multi-scale analysis deciphering transitions in fluid flow over time and their relation to the present-day geothermal activity is described in a separate contribution (Tannock et al., submitted). 
In the following sections we constrain the temperature estimates and identify static and dynamic criteria for the formation of the giant quartz reef.

9.1. Temperature constraints during the evolution of Heyuan fault zone

Mica geothermometry was consistent with microstructural dynamic recrystallisation observations in the mylonite samples $\left(\sim 330^{\circ} \mathrm{C}\right)$. However, the equilibration conditions of the mica in the quartz reef are $\sim 370^{\circ} \mathrm{C}$, which is inconsistent with most quartz microstructures indicating brittle conditions to low temperature plasticity (i.e. below $280 \pm 30^{\circ} \mathrm{C}$ (Stipp et al., 2002b; Stöckhert et al., 1999). The relationship between the mica and the quartz, appears entirely hydrothermally grown in-situ, and the absence of any other significant minerals e.g. feldspar, chlorite, would indicate that the mica has not been transported as a detrital rock fragment. Therefore, the textural neighbourhood of the quartz microstructures and the mica growth ask for the meaning of such disparity.

The interpretation of the quartz microstructure is robust by numerous reported examples in nature. While the mica geothermometry is stated to have a uncertainty of up to $\pm 50^{\circ} \mathrm{C}$ (Dubacq et al., 2010; Lanari et al., 2014a, 2014b), the mica data for this study appear relatively robust due to the majority of mica samples in the quartz reef resulting in the same elevated temperature within a small margin of error (Table 5). The assumed equilibration (quartz + mica + aqueous fluid) is best fulfilled in a quartz reef. However, conclusive conclusions cannot be drawn based on comparison between two different techniques, and can only be indicative of potential mechanisms, which we discuss below. Further work, including fluid inclusion studies would be required to affirm this.

We propose the cause of this disparity is most likely a result of hot 'K/Al-bearing' fluids $\left(\sim 370^{\circ} \mathrm{C}\right)$ being injected into the relatively cooler quartz reef $\left(<310^{\circ} \mathrm{C}\right)$, at high velocity, e.g. 
by means of mobile hydrofracture (Bons, 2001) or via episodic pulses associated with fluid pumping (e.g. Sibson et al., 1975) thus creating a pressure-temperature variation and dynamic permeability across the quartz reef.

\subsection{Quasi-static criteria for a quartz reef window}

A set of static criteria has been derived from the aforementioned microstructural and geochemical observations for the formation of the quartz reef within an optimum window. These criteria align with observation across other known giant quartz reef formations (Table $6)$.

\subsubsection{Accommodation space}

Significant accommodation space in which the quartz reef can 'grow'; as determined by the tectonic setting e.g. extensional regimens (such as the Heyuan fault), or dilatational jogs associated with strike-slip faulting (e.g. Kerrich \& Feng 1992; Hippertt \& Massucatto 1998; Gandhi et al. 2000; Lemarchand et al. 2012; Schaarschmidt et al. 2018).

From the microstructural observations and geothermometric analyses, this space is associated with formation at the brittle-ductile transition, and in the optimum temperature window (approximately $200-350^{\circ} \mathrm{C}$ ), which is consistent with observations in other giant quartz reefs (Table 6).

\subsubsection{Massive fluid sources}

Considerable Time-Integrated Fluid Fluxes (TIFF) are necessary to transport such huge masses. Due to the significant fluid volume necessary, multiple fluid sources are likely to 
be required. Giant quartz reefs elsewhere have shown sources to come from mixed sources (Gandhi et al., 2000) of deep to mid crustal metamorphic dehydration (Kerrich and Feng, 1992), and later meteoric recharge (Lemarchand et al., 2012). At the Heyuan fault, there is evidence of fluid contribution from three sources: i) metamorphic dehydration reaction from the phyllonite; ii) meteoric recharge indicated from hot spring isotope studies (Qiu et al., 2018); and iii) potential mantle or deep crustal source indicated from the presence of Cr-oxide and Cr-micas in the quartz reef. The notion and mechanism of deeper external fluid sources contributing to the system is discussed below (section 9.3.3).

Downward flow of meteoric fluids could potentially occur via large-scale convection cells (Etheridge et al., 1983). However it is questioned if fluid mixing can occur by means of meteoric recharge meeting the upward crustal fluids, if fluid pressures are above hydrostatic pressure required to achieve fracturing it would effectively prevent downward flow (Bons et al., 2012), though 'fault-valve' mechanisms (Sibson, 1992), and ductile fracture pumping may mitigate this. It certainly appears evident that sufficient fluid volume is required to (a) dissolve enough material for upward and lateral fluid motion in the fault zone, and (b) precipitate it over geological time scales in enormous volumes.

\subsubsection{Cap Rock/Seal}

Quartz precipitation occurs due to an oversaturation in $\mathrm{SiO}_{2}$ in the fluid owing to (a) temperature decrease, (b) pressure drop or (c) fluid mixing (e.g. change in $\mathrm{pH}$ (Henderson et al., 1970; Krauskopf, 1956), or salinity (Shmulovich et al., 2006)). While in the case of the Heyuan fault system there is evidence to suspect fluid mixing e.g. meteoric input (Qiu et al., 2018), potential deeper Cr-bearing fluid sources and metamorphic reaction fluids; there is strong evidence to suggest the role of an overlying seal in the formation of the quartz reef. Namely: i) the overlying low permeability phyllonite creates a physical barrier to vertical fluid 
migration and marks the termination of the quartz reef; ii) the presence of a cap rock/seal at other giant quartz reefs worldwide (e.g. Hippertt and Massucatto, 1998; Schaarschmidt et al., 2019); iii) the mechanism by which a seal, or other pre-existing structure may trigger mineral precipitation through sudden arrest of a fluid in disequilibrium transported at high velocity, e.g. during fault rupture (Sibson, 2000, 1988), or transported as mobile hydrofractures (Bons, 2001). In addition to acting as a potential component for triggering precipitation, the overlying seal would allow the fluids to be channelized and trapped (i.e. no pervasive flux) and prevent producing widespread veining (e.g. Simplon fault zone: Campani et al., 2010; Haertel and Herwegh, 2014; Mancktelow, 1985) or the Raft River detachment (Gottardi and Teyssier, 2013), as opposed to a consolidated giant quartz reef like the Heyuan exhibits. These mechanisms and supporting evidence of them occurring at the Heyuan fault are further discussed below in in the "dynamic criteria".

9.3. Spatial, temporal dynamic criteria for a quartz reef window

\subsubsection{Episodic-dynamic permeability}

In order to channel the fluid flow from the source to precipitate and forms the quartz reef, sufficient permeability must exist. In a hydrothermal system in fractured crystalline granitic rock, such at the Heyuan fault, this permeability is most likely dynamic in nature.

Detailed microstructural analysis in the quartz reef identified several mechanisms acting to increase permeability (fracture modes and cataclasis) and decrease permeability (hydrothermal

growth) (Section 6). These mechanisms appeared to be i) cyclical, and ii) intimately linked within decreasing grain-size generations. These generations also appear to correlate with the changing tectonic stress field from the Mesozoic extension, to the Cenozoic compressional phase; as mode-I void opening and growth transcends through, cataclasis, neo-crystallisation, 
incremental 'crack-seal' type behaviour (Petit et al., 1999; Ramsay, 1980), and lastly to shear fracture abrasion. This latest event can be related to the sub-vertical fracturing seen on the outcrop scale, which are also largely unmineralized. These are likely a result of the younger strike-slip faulting which continues to present day.

On short-timescales, periodic pulses enhance the permeability, which then become clogged by sealing processes which can build over longer timescales. This periodic fault permeability is interpreted in geological models as seismic events that creates fracturing, which is then closed during hydrothermal mineral precipitation during quiescence; providing fluid flow in episodes rather than continuously (Barton et al., 1995; Bruhn et al., 1994; Caine et al., 1996; Morrow et al., 2001). These studies showed that fluid flow occurred in cycles, which is consistent with the findings of this research.

\subsubsection{Brittle-ductile cycles}

At depth, the initial strain localization took place from the granite to mylonite, where dramatic grain size reduction occurred as a result of crystal plastic deformation including dynamic recrystallisation in the quartz (Figure 6). The ductile deformation of the granite i.e. viscous granular flow (diffusion creep via grain boundary sliding, solution-precipitation and diffusive mass transfer processes), resulting in generation of fine-grained polymineralic ultramylonites (e.g. Herwegh et al., 2011; Stunitz, 1993; Wehrens et al., 2016).

The new hydrous minerals within the mylonite matrix, such as epidote, white mica, and chlorite, suggest the presence of water in the system, providing mechanical lubrication for the fault movement. Initial veining episodes including precipitation of chlorite and epidote occurred syn-kinematically with the mylonite formation; with the earliest quartz veins 
following syn-kinematically, all subsequently being deformed in a ductile manner to align with the mylonite foliation (Table 2, Figure and 12). This is evident from i) the highly deformed manner in which the veins are disrupted, often appearing disconnected; and ii) localised truncation of veins following subsequent mylonitisation phases (Figures 3e and 6i), thus arguing against the idea that the veins formed in fractures following the mylonite foliation.

It would be unlikely that that the temperature and/or depth of these samples could fluctuate to facilitate the cycles between brittle fracturing and ductile deformation, unless there was enough influence through the temperature differential of an injected fluid and subsequent cooling. This implies that the associated process occurred through episodic brittle events where strain rates suddenly increase to create brittle fracturing, precipitation, then healing as strain rate decreases. Similar brittle-ductile cycles have been documented from quartz microstructures in the Sesia Zone, Western Alps, which Trepmann and Stöckhert (2003) conclude as being stresscontrolled (as opposed to temperature-controlled) and can provide insight into earthquake cycles. To differentiate between vein formation in the cool, brittle domain, we term these "hot veins". These ductile-brittle cycles therefore appear to represent evidence of seismicity in the high temperature domain $\left(\sim 330^{\circ} \mathrm{C}\right)$.

The early quartz vein generations signify the onset of the formation of the quartz reef with continued formation post mylonitisation, and throughout the cataclastic phases. This is evident from continued fluid flow and precipitation through the extensive sealing and neocrystallisation within these facies. 


\subsubsection{Brittle-ductile fault-valve behaviour}

Fluid injection at the brittle-ductile transition is inferred to cause so-called Non-Volcanic Tremor (NVT) events also known as episodic tremor and slip (Becken et al., 2011; Beroza and Ide, 2011; Obara, 2002). They typically are observed in seismograms at higher intensity above the background noise. However, based on these geophysical data and their limited spatial resolution below the 100-10 m scale, exhumed fossil fault zones such as the Heyuan system provide the opportunity to share new light onto the geometries, the spatial distribution and long-term temporal evolution of such systems. In the case of the Heyuan fault zone, episodic fluid cycles are very prominent, operating at different depths: (i) with brittle fracturing in the ductile mylonitic zone indicating fast slip (NVT), followed by vein mineral precipitation and sealing; (ii) brittle deformation and dilation creating cataclasites in the brittle dominated crustal levels, followed by subsequent mineral precipitation in the cavities, eventually sealing the formation, as similarly reported at the Bavarian Pfahl (Yilmaz et al., 2014); and (iii) fracturing of the quartz reef, followed by later mineral infill and resealing (Figures 11 and 12). Thus, hydrothermal fluids channeling up from depth, would percolate through these different crustal stockworks in a very dynamic manner. Therefore, we infer that migration of fluids triggers seismic pulses (NVT's), which are caused by the hydro-mechanical link between a fault that is dynamically lubricated through episodic fluid release processes. This process could be interpreted as the brittle-ductile equivalent of the fault-valve model by Sibson (1990). In such a model, the pore pressure would be seen to change from hydrostatic to lithostatic at the brittleductile transition as a result of building pressure beneath the sealing 'phyllonite cap' rock, even in extensional settings (Hunt, 1990), which can trigger fault-valve-like behaviour if overpressure occurs (Sibson 1990; Sibson 2000).

Supporting evidence for the sudden ascent and arrest of these fluids comes from: 
i. The above described brittle-ductile cycles observed in the mylonite, indicating episodes of sudden brittle fracturing, possibility as a consequence of seismic activity and subsequent fluid flow.

ii. Elevated mica-bearing fluid temperature, shown from the geothermometry, relative to the surrounding quartz reef microstructures $\left(>60^{\circ} \mathrm{C}\right.$ differential), indicating potential hot fluid pulses (as discussed above).

iii. Mass balance calculations that estimated that the phyllonite could have contributed a minimum of $37.5 \mathrm{~m}$ thickness to the quartz reef, in a similar process to that at reported at Cavalcante-Teresina, central Brazil (Hippertt and Massucatto, 1998). However, neither the phyllonite nor the mylonite can account for the total fluid volume required to form the reef through dissolution-precipitation reactions. Therefore, outside fluid sources must have contributed to the formation of the quartz reef in order to generate to $>75 \mathrm{~m}$ thickness ( $+75 \mathrm{~m}$ hydrothermal cataclasite) observed today. While the minor amounts of Cr-oxide found throughout the formation should not be used as conclusive evidence, it may signify a deep/mantle source of the fluid, which warrants further investigation.

\section{Conclusions}

The systematic analysis of the largely un-researched system at the Heyuan geothermal fault zone and giant quartz reef core, from initial field reconnaissance to microstructural observations, highlight the cyclical nature of the fault zone permeability due to repeated rapid fluid injection and hydrothermal fluid precipitation sealing. 
The complex internal structure of the quartz reef is shown to have formed via several mechanisms, which can be related to the changing conditions and stress regime from extension to compressional/strike-slip influenced over time. This can be summarised as follows (i) large idiomorphic crystal growth into void space, potentially associated with the quiescence period between seismic events; (ii) fast slip events, during seismic activity, generating cataclastic regions in the reef which later neo-crystallise and grow due to subsequent fluid flow; (iii) incremental fracture opening marked by reactivation and slip along previous mode-I fractures, signifies the turning point in the tectonic stress regime from extensional to compressional; (iv) sub-vertical, unmineralized shear fractures form as a result of cross-cutting strike-slip faults which developed under the new compressional regime on the Heyuan fault. This sub-vertical fracture network is proposed as the more recent fluid flow pathway supplying the present-day hot springs.

The current fluid flow pathway is the focus of a the multiscale investigation (Tannock et al., submitted). Further research to constrain the P-T conditions is required, e.g. fluid inclusions studies, which are planned for the next phase of the project.

We propose the following quasi-static criteria (accommodation space; massive fluid sources; and cap rock/seal) and dynamic mechanisms are at play in the formation of a giant quartz reef: i) episodic-dynamic permeability; ii) brittle-ductile cycles; and ii) fluid injection though brittle-ductile equivalent of Sibson (1990) fault valve behaviour, with rapid ascent and arrest bringing up significant volumes of fluid at high rate in disequilibrium and enabling $\mathrm{SiO}_{2}$ precipitation though sudden arrest at the seal.

These findings can be used to help understand permeability evolution in other geothermal fault zones where the silica precipitation at depth has not been exposed at surface. 


\section{Acknowledgments}

This work has been carried out under the support of an Australian Government Research Training Program Scholarship. Additional funding for this research has been provided by the Australian Research Council (ARC DP170104550, DP170104557) and the strategic SPF01 fund of UNSW, Sydney. Finally, we gratefully acknowledge the collaboration of Guangdong Nonferrous Geological Environment Centre, the 292 Brigade of Guangdong Province Nuclear Industry Geological Bureau, Prof. Ke Zhang and Prof. Hepin Zou of Sun Yat-sen University. We very much thank the careful and helpful reviews of Jörn Kruhl, Paul Bons and an anonymous reviewer. The editorial work of Joao Hippertt is also greatly acknowledged.

\section{References}

Airaghi, L., Lanari, P., de Sigoyer, J., Guillot, S., 2017. Microstructural vs compositional preservation and pseudomorphic replacement of muscovite in deformed metapelites from the Longmen Shan (Sichuan, China). Lithos 282-283, 262-280. https://doi.org/10.1016/j.lithos.2017.03.013

Barton, C.A., Zoback, M.D., Moos, D., 1995. Fluid flow along potencially active faults in crystalline rock. Geology 23, 683-686. https://doi.org/10.1130/0091$7613(1995) 023<0683$

Becken, M., Ritter, O., Bedrosian, P.A., Weckmann, U., 2011. Correlation between deep fluids, tremor and creep along the central San Andreas fault. Nature 480, 87-90. https://doi.org/10.1038/nature10609

Berger, A., Wehrens, P., Lanari, P., Zwingmann, H., Herwegh, M., 2017. Microstructures, mineral chemistry and geochronology of white micas along a retrograde evolution: An example from the Aar massif (Central Alps, Switzerland). Tectonophysics 721, 179- 
195. https://doi.org/10.1016/j.tecto.2017.09.019

Beroza, G.C., Ide, S., 2011. Slow Earthquakes and Nonvolcanic Tremor. Annu. Rev. Earth Planet. Sci. 39, 271-296. https://doi.org/10.1146/annurev-earth-040809-152531

Bons, P.D., 2001. The formation of large quartz veins by rapid ascent of fluids in mobile hydrofractures. Tectonophysics 336, 1-17. https://doi.org/10.1016/S00401951(01)00090-7

Bons, P.D., Elburg, M.A., Gomez-Rivas, E., 2012. A review of the formation of tectonic veins and their microstructures. J. Struct. Geol. 43, 33-62. https://doi.org/10.1016/j.jsg.2012.07.005

Bruhn, R.L., Parry, W.T., Yonkee, W. a, Thompson, T., 1994. Fracturing and hydrothermal alteration in normal fault zones. Pure Appl. Geophys. 142, 609-644. https://doi.org/10.1007/BF00876057

Caine, J.S., Evans, J.P., Forster, C.B., 1996. Fault zone architechture and permeability structure. Geology 24, 1025-1028. https://doi.org/10.1130/0091-7613(1996)024<1025

Campani, M., Mancktelow, N., Seward, D., Rolland, Y., Müller, W., Guerra, I., 2010. Geochronological evidence for continuous exhumation through the ductile - brittle transition along a crustal - scale low - angle normal fault : Simplon Fault Zone , central Alps. Tectonics 29. https://doi.org/10.1029/2009TC002582

Cantarero, I., Lanari, P., Vidal, O., Alías, G., Travé, A., Baqués, V., 2014. Long-term fluid circulation in extensional faults in the central Catalan Coastal Ranges: P-T constraints from neoformed chlorite and K-white mica. Int. J. Earth Sci. 103, 165-188. https://doi.org/10.1007/s00531-013-0963-8

Chen, L., Talwani, P., 1998. Reservoir-induced Seismicity in China. Pure Appl. Geophys. 153, 133-149. https://doi.org/10.1007/s000240050188

Cheng, H.H., Zhang, H., Zhu, B.J., Sun, Y.J., Zheng, L., Yang, S.H., Shi, Y.L., 2012. Finite 
element investigation of the poroelastic effect on the Xinfengjiang Reservoir-triggered earthquake. Sci. China Earth Sci. 55, 1942-1952. https://doi.org/10.1007/s11430-012$4470-8$

Ding, Y.Z., 1989. The reservoir-induced earthquakes in China. South Chin J Seismol. 9, 6472.

Dubacq, B., Vidal, O., de Andrade, V., 2010. Dehydration of dioctahedral aluminous phyllosilicates: Thermodynamic modelling and implications for thermobarometric estimates. Contrib. to Mineral. Petrol. 159, 159-174. https://doi.org/10.1007/s00410009-0421-6

Etheridge, M.A., Wall, V.J., Vernon, R.H., 1983. The role of the fluid phase during regional metamorphism and deformation. J. Metamorph. Geol. 1, 205-226. https://doi.org/10.1111/j.1525-1314.1983.tb00272.x

Evans, B., Renner, J., Hirth, G., 2001. A few remarks on the kinetics of static grain growth in rocks. Int. J. Earth Sci. 90, 88-103. https://doi.org/10.1007/s005310000

Ferrero, S., Lanari, P., Goncalves, P., Grosch, E.G., 2019. Metamorphic Geology: Microscale to Mountain Belts, Geological Society of London Special Publications. Geological Society Publishing House.

Gandhi, S.S., Carrière, J.J., Prasad, N., 2000. Implications of a preliminary fluid- inclusion study of giant quartz veins of the southern Great Bear magmatic zone, Northwest Territories.

Gottardi, R., Teyssier, C., 2013. Thermomechanics of an extensional shear zone, Raft River metamorphic core complex, NW Utah. J. Struct. Geol. 53, 54-69. https://doi.org/10.1016/j.jsg.2013.05.012

Guillope, M., Poirier, J.P., 1979. Dynamic recrystallization during creep of single-crystalline halite: An experimental study. J. Geophys. Res. 84, 5557. 
https://doi.org/10.1029/JB084iB10p05557

Haertel, M., Herwegh, M., 2014. Microfabric memory of vein quartz for strain localization in detachment faults: A case study on the Simplon fault zone. J. Struct. Geol. 68, 16-32. https://doi.org/10.1016/j.jsg.2014.08.001

Handy, M.R., Hirth, G., Bürgmann, R., 2007. Continental fault structure and rheology from the frictional-to-viscous transition downward. Tecton. Faults Agents Chang. a Dyn. Earth 139-181. https://doi.org/10.23919/ChiCC.2017.8027435

Henderson, J.H., Syers, J.K., Jackson, M.L., 1970. Quartz Dissolution as Influenced by pH and the Presence of a Disturbed Surface Layer. Isr. J. Chem. 8, 357-372. https://doi.org/10.1002/ijch.197000042

Herwegh, M., Linckens, J., Ebert, A., Berger, A., Brodhag, S.H., 2011. The role of second phases for controlling microstructural evolution in polymineralic rocks: A review. J. Struct. Geol. 33, 1728-1750. https://doi.org/10.1016/j.jsg.2011.08.011

Hillig, W.B., 1966. A derivation of classical two-dimensional nucleation kinetics and the associated crystal growth laws. Acta Metall. 14, 1868-1869.

Hippertt, J.F., Massucatto, A.J., 1998. Phyllonitization and development of kilometer-size extension gashes in a continental-scale strike-slip shear zone, north Goiás, central Brazil. J. Struct. Geol. 20, 433-445. https://doi.org/10.1016/S0191-8141(97)00106-5 Hunt, J.M., 1990. Generation and migration of petroleum from abnormally pressured fluid compartments. Am. Assoc. Pet. Geol. Bull. 74, 1-12. https://doi.org/10.1306/0C9B21EB-1710-11D7-8645000102C1865D

Inoue, A., Inoué, S., Utada, M., 2018. Application of chlorite thermometry to estimation of formation temperature and redox conditions. Clay Miner. 53, 143-158. https://doi.org/10.1180/clm.2018.10

Kelsey, C.H., 1965. Calculation of the CIPW norm. Mineral. Mag. J. Mineral. Soc. 34, 276- 
282. https://doi.org/10.2146/ajhp150367

Kerrich, R., Feng, R., 1992. Archean geodynamics and the Abitibi-Pontiac collision:

implications for advection of fluids at transpressive collisional boundaries and the origin of giant quartz vein systems. Earth Sci. Rev. 32, 33-60. https://doi.org/10.1016/00128252(92)90011-H

Krauskopf, K.B., 1956. Dissolution and precipitation of silica at low temperatures. Geochim. Cosmochim. Acta 10, 1-26. https://doi.org/10.1016/0016-7037(56)90009-6

Lanari, P., 2012. Micro-cartographie PT-» dans les roches métamorphiques. Applications aux Alpes et à l'Himalaya. Université de Grenoble.

Lanari, P., Guillot, S., Schwartz, S., Vidal, O., Tricart, P., Riel, N., Beyssac, O., 2012. Diachronous evolution of the alpine continental subduction wedge: Evidence from $\mathrm{P}-\mathrm{T}$ estimates in the Briançonnais Zone houillère (France - Western Alps). J. Geodyn. 5657, 39-54. https://doi.org/10.1016/j.jog.2011.09.006

Lanari, P., Rolland, Y., Schwartz, S., Vidal, O., Guillot, S., Tricart, P., Dumont, T., 2014a. PT-t estimation of deformation in low-grade quartz-feldspar-bearing rocks using thermodynamic modelling and $40 \mathrm{Ar} / 39 \mathrm{Ar}$ dating techniques: example of the Plan-dePhasy shear zone unit (Briançonnais Zone, Western Alps). Terra Nov. 26, 130-138. https://doi.org/10.1111/ter.12079

Lanari, P., Wagner, T., Vidal, O., 2014b. A thermodynamic model for di-trioctahedral chlorite from experimental and natural data in the system MgO-FeO-Al2O3-SiO2-H2O: Applications to P-T sections and geothermometry. Contrib. to Mineral. Petrol. 167, 119. https://doi.org/10.1007/s00410-014-0968-8

Lee, C.F., Ye, H., Zhou, Q., 1997. On the potential seismic hazard in Hong Kong. Episodes 20, 89-94.

Lemarchand, J., Boulvais, P., Gaboriau, M., Boiron, M.-C., Tartèse, R., Cokkinos, M., 
Bonnet, S., Jégouzo, P., 2012. Giant quartz vein formation and high-elevation meteoric fluid infiltration into the South Armorican Shear Zone: geological, fluid inclusion and stable isotope evidence. J. Geol. Soc. London 169, 17-27. https://doi.org/10.1144/0016$76492010-186$

Li, Z.X., Li, X.H., 2007. Formation of the 1300-km-wide intracontinental orogen and postorogenic magmatic province in Mesozoic South China: A flat-slab subduction model. Geology 35, 179-182. https://doi.org/10.1130/G23193A.1

Liu, R., Xie, G., Zhou, X., Chen, W., Fan, Q., 1995. Tectonic environments of Cenozoic volcanic rocks in China and characteristics of the source regions in the mantle. Chinese J. Geochemistry 14, 289-302. https://doi.org/10.1007/BF02872628

Mancktelow, N.S., 1985. The Simplon Line : a major displacement zone in the western Lepontine Alps The Simplon Line : a major displacement zone in the western Lepontine Alps By. Eclogae Geol. Helv. 78, 73-96.

Morrow, C.A., Moore, D.E., Lockner, D.A., 2001. Permeability reduction in granite under hydrothermal conditions. J. Geophys. Res. Solid Earth 106, 30551-30560. https://doi.org/10.1029/2000jb000010

O’Hara, K., 1988. Fluid flow and volume loss during mylonitization: an origin for phyllonite in an overthrust setting, North Carolina U.S.A. Tectonophysics 156, 21-36. https://doi.org/10.1016/0040-1951(88)90280-6

Obara, K., 2002. Nonvolcanic deep tremor associated with subduction in southwest Japan. Science (80-. ). 296, 1679-1681. https://doi.org/10.1126/science.1070378

Petit, J.P., Wibberley, C.A.J., Ruiz, G., 1999. “Crack-seal”, slip: A new fault valve mechanism? J. Struct. Geol. 21, 1199-1207. https://doi.org/10.1016/S01918141(99)00038-3

Qiu, X., Fenton, C., 2015. Factors Controlling the Occurrence of Reservoir-Induced 
Seismicity. Eng. Geol. Soc. Territ. - Vol. 6 567-570. https://doi.org/10.1007/978-3-31909060-3_102

Qiu, X., Wang, Y., Wang, Z., Regenauer-Lieb, K., Zhang, K., Liu, J., 2018. Determining the origin, circulation path and residence time of geothermal groundwater using multiple isotopic techniques in the Heyuan Fault Zone of Southern China. J. Hydrol. 567, 339350. https://doi.org/https://doi.org/10.1016/j.jhydrol.2018.10.010

Ramsay, J.G., 1980. The crack-seal mechanism of rock deformation. Nature 284, 135-139. https://doi.org/10.1038/284135a0

Schaarschmidt, A., Haase, K.M., de Wall, H., Bestmann, M., Krumm, S., Regelous, M., 2019. Upper crustal fluids in a large fault system: microstructural, trace element and oxygen isotope study on multi-phase vein quartz at the Bavarian Pfahl, SE Germany. Int. J. Earth Sci. 108, 521-543. https://doi.org/10.1007/s00531-018-1666-y

Schmid, S.M., Handy, M.R., 1991. Towards a genetic classification of fault rocks: Geological usage and tectonophysical implications, in: Müller DW, McKenzie JA, Weissert H (Eds) Controversies in Modern Geology, Evolution of Geological Theories in Sedimentology, Earth History and Tectonics. Academic Press, London, pp. 339-361.

Schneider, C.A., Rasband, W.S., Eliceiri, K.W., 2012. NIH Image to ImageJ: 25 years of image analysis. Nat. Methods 9, 671-675. https://doi.org/10.1038/nmeth.2089

Shmulovich, K.I., Yardley, B.W.D., Graham, C.M., 2006. Solubility of quartz in crustal fluids: Experiments and general equations for salt solutions and $\mathrm{H} 2 \mathrm{O}-\mathrm{CO} 2$ mixtures at 400-800 ${ }^{\circ} \mathrm{C}$ and 0.1-0.9 GPa. Geofluids 6, 154-167. https://doi.org/10.1111/j.14688123.2006.00140.x

Sibson, R.H., 2000. Fluid involvement in normal faulting. J. Geodyn. 29, 469-499. https://doi.org/10.1016/S0264-3707(99)00042-3

Sibson, R.H., 1992. Fault-valve behavior and the hydrostatic-lithostatic fluid pressure 
interface. Earth Sci. Rev. 32, 141-144. https://doi.org/10.1016/0012-8252(92)90019-P

Sibson, R.H., 1990. Conditions for fault-valve behaviour. Geol. Soc. London, Spec. Publ. 54, 15-28. https://doi.org/10.1144/GSL.SP.1990.054.01.02

Sibson, R.H., 1989. Earthquake faulting as a structural process. J. Struct. Geol. 11, 1-14. https://doi.org/10.1016/0191-8141(89)90032-1

Sibson, R.H., 1988. Earthquake Rupturing As A Mineralizing Agent In Hydrothermal Systems. Geology 16, 670. https://doi.org/10.1130/0091-7613(1987)15<701

Sibson, R.H., Moore, J.M.M., Rankin, A.H., 1975. Seismic pumping-a hydrothermal fluid transport mechanism. J. Geol. Soc. London. 131, 653-659. https://doi.org/10.1144/gsjgs.131.6.0653

Sibson, R.H., Robert, F., Poulsen, K.H., 1988. High-angle reverse faults, fluid-pressure cycling, and mesothermal gold-quartz deposits. Geology 16, 551. https://doi.org/10.1130/0091-7613(1988)016<0551:HARFFP>2.3.CO;2

Song, W.J., Ree, J.H., 2007. Effect of mica on the grain size of dynamically recrystallized quartz in a quartz-muscovite mylonite. J. Struct. Geol. 29, 1872-1881. https://doi.org/10.1016/j.jsg.2007.09.011

Stipp, M., Stünitz, H., Heilbronner, R., Schmid, S.M., 2002a. Dynamic recrystallization of quartz: correlation between natural and experimental conditions. Geol. Soc. London, Spec. Publ. 200, 171-190. https://doi.org/10.1144/GSL.SP.2001.200.01.11

Stipp, M., Stünitz, H., Heilbronner, R., Schmid, S.M., 2002b. The eastern Tonale fault zone: A “natural laboratory" for crystal plastic deformation of quartz over a temperature range from 250 to $700{ }^{\circ}$ C. J. Struct. Geol. 24, 1861-1884. https://doi.org/10.1016/S01918141(02)00035-4

Stöckhert, B., Brix, M.R., Kleinschrodt, R., Hurford, A.J., Wirth, R., 1999.

Thermochronometry and microstructures of quartz-a comparison with experimental flow 
laws and predictions on the temperature of the brittle-plastic transition. J. Struct. Geol. 21, 351-369. https://doi.org/10.1016/S0191-8141(98)00114-X

Stunitz, H., 1993. Transition from fracturing to viscous flow in a naturally deformed metagabbro, in: Defects and Processes in the Solid State: Geoscience Applications: The McLaren Volume (Developments in Petrology). Elsevier, pp. 121-150.

Tang, S.L., Yan, D.P., Qiu, L., Gao, J.F., Wang, C.L., 2014. Partitioning of the Cretaceous Pan-Yangtze Basin in the central South China Block by exhumation of the Xuefeng Mountains during a transition from extensional to compressional tectonics? Gondwana Res. 25, 1644-1659. https://doi.org/10.1016/j.gr.2013.06.014

Tannock, L., Herwegh, M., Berger, A., Liu, J., Regenauer-lieb, K., 2019. The Effects of a Tectonic Stress Regime Change on Crustal-Scale Fluid Flow at the Heyuan Geothermal Fault, South China. (Submitted).

Trepmann, C.A., Stöckhert, B., 2003. Quartz microstructures developed during non-steady state plastic flowat rapidly decaying stress and strain rate. J. Struct. Geol. 25, 20352051. https://doi.org/10.1016/S0191-8141(03)00073-7

Trincal, V., Lanari, P., Buatier, M., Lacroix, B., Charpentier, D., Labaume, P., Muñoz, M., 2015. Temperature micro-mapping in oscillatory-zoned chlorite: Application to study of a green-schist facies fault zone in the Pyrenean Axial Zone (Spain). Am. Mineral. 100, 2468-2483. https://doi.org/10.2138/am-2015-5217

Vidal, O., De Andrade, V., Lewin, E., Munoz, M., Parra, T., Pascarelli, S., 2006. P-Tdeformation-Fe3+/Fe2+ mapping at the thin section scale and comparison with XANES mapping: Application to a garnet-bearing metapelite from the Sambagawa metamorphic belt (Japan). J. Metamorph. Geol. 24, 669-683. https://doi.org/10.1111/j.15251314.2006.00661.x

Vidal, O., Lanari, P., Munoz, M., Bourdelle, F., De Andrade, V., 2016. Deciphering 
temperature, pressure and oxygen-activity conditions of chlorite formation. Clay Miner. 51, 615-633. https://doi.org/10.1180/claymin.2016.051.4.06

Wan, T., 2012. the Tectonics of China: Data, Maps and Evolution. Springer Berlin Heidelberg.

Wang, A.D., Sun, Z.X., Hu, B.Q., Liu, J.H., Liu, C.D., 2014. Guangdong, a Potential Province for Developing Hot Dry Rock Geothermal Resource. Appl. Mech. Mater. 492, 583-585. https://doi.org/10.4028/www.scientific.net/AMM.492.583

Wehrens, P., Berger, A., Peters, M., Spillmann, T., Herwegh, M., 2016. Deformation at the frictional-viscous transition: Evidence for cycles of fluid-assisted embrittlement and ductile deformation in the granitoid crust. Tectonophysics $693,66-84$. https://doi.org/10.1016/j.tecto.2016.10.022

Yilmaz, T.I., Prosser, G., Liotta, D., Kruhl, J.H., Gilg, H.A., 2014. Repeated hydrothermal quartz crystallization and cataclasis in the Bavarian Pfahl shear zone (Germany). J. Struct. Geol. 68, 158-174. https://doi.org/10.1016/j.jsg.2014.09.004

Zhou, X.M., Sun, T., Shen, W., Shu, L., Niu, Y., 2006. Petrogenesis of Mesozoic granitoids and volcanic rocks in south China: a response to tectonic evolution. Episodes 26-33. https://doi.org/10.18814/epigsi/2006/v29i1/62224 
Figures \& Tables

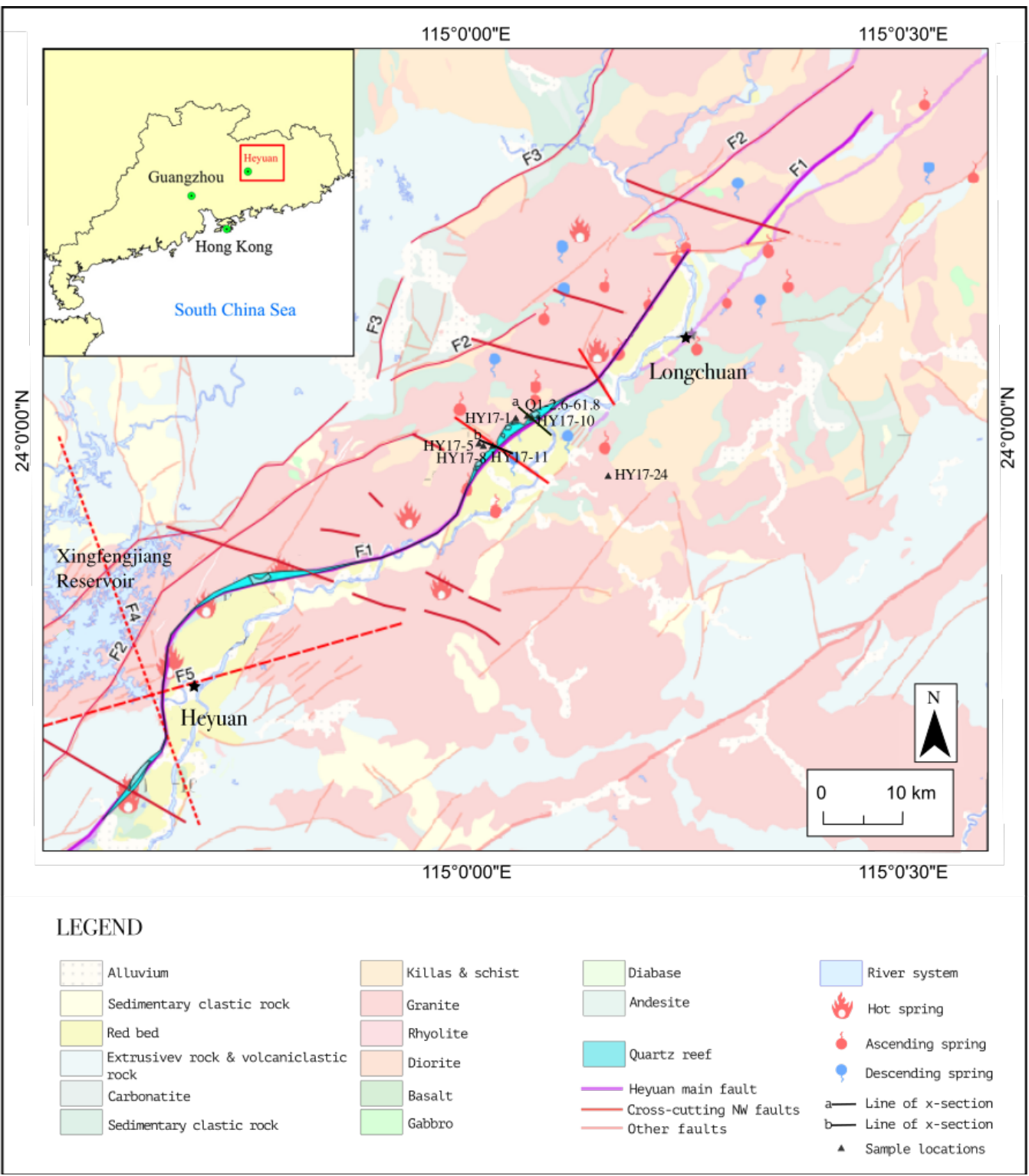

Figure 1a. Overview map (inset) depicting the location of the larger study area; Figure 1b. Geological map of the of the larger study area encompassing the main section of the Heyuan fault. The quartz reef is shown along the Heyuan fault, with visible outcrops highlighted. Related faults are shown along with the major granitic plutons, hot springs and sample locations. Major faults: F1-Heyuan fault; F2-Renzishi Fault; F3-Daping-Yanqian Fault; F4-Shijiao-Xingang-Baitian fault; F5-Nanshan-Aotou Fault. Major plutons include: 2- Xingfengjiang, 4Baishigang, 5-Longwo. Modified from (Qiu et al., 2018). Sample HY17-1 marks the location of Xinfeng granite quarry, and samples Q1-2.6-61.8 from Leiyao quartz mine. 
(a)
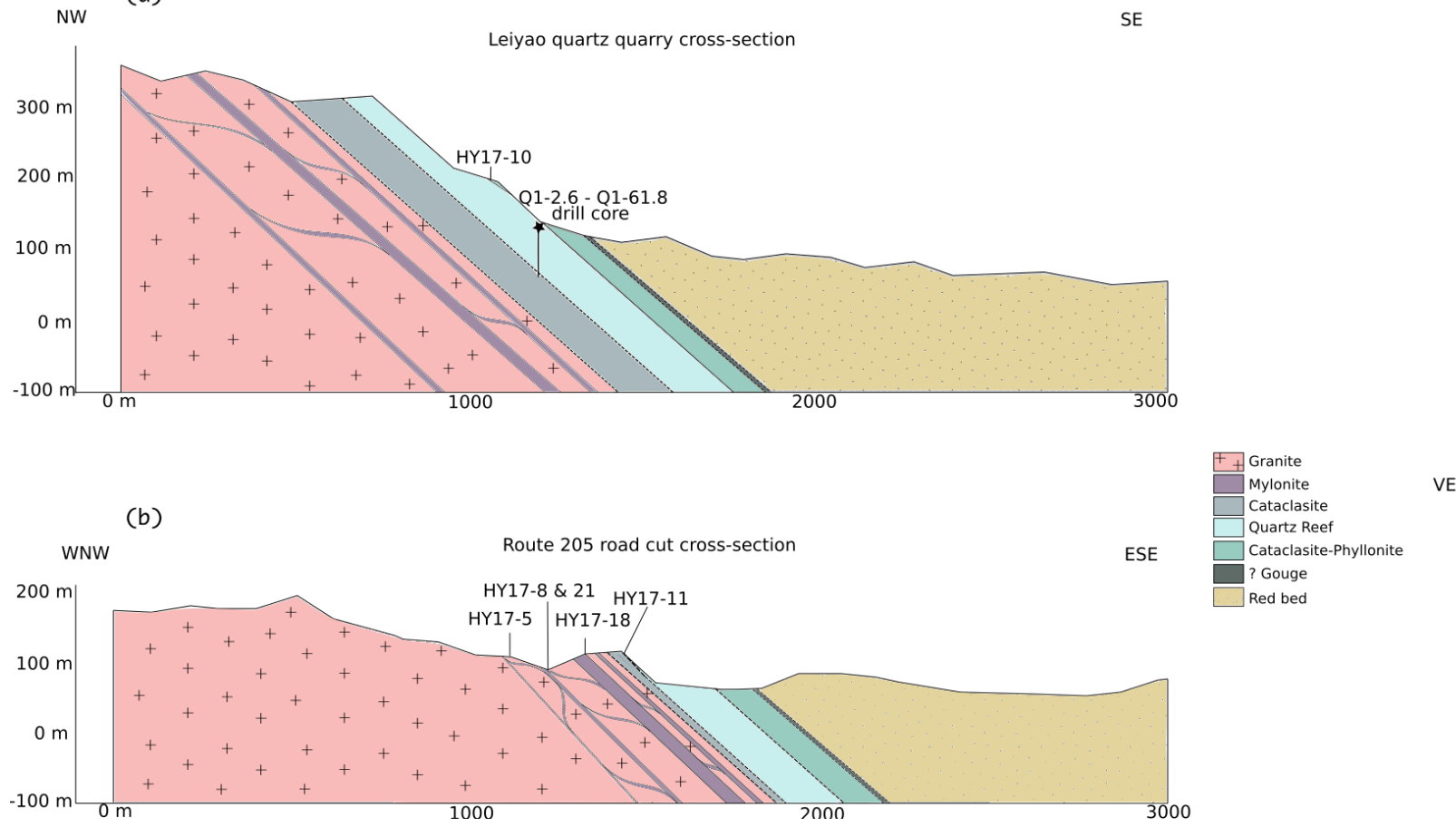

Figure 2. Cross sections through the Heyuan fault at the study area (shown in Fig 1), with sample locations highlighted. (a) NW-SE section traverses through the Leiyao quartz mine site where core samples Q1 2.6 through 61.8 were obtained, as well as an outcrop sample of ultracataclasite overlying the quartz reef (HY17-10). (b) WNWESE section where samples were obtained in outcrop along the route 205 road-cut which provided access to the faul1 

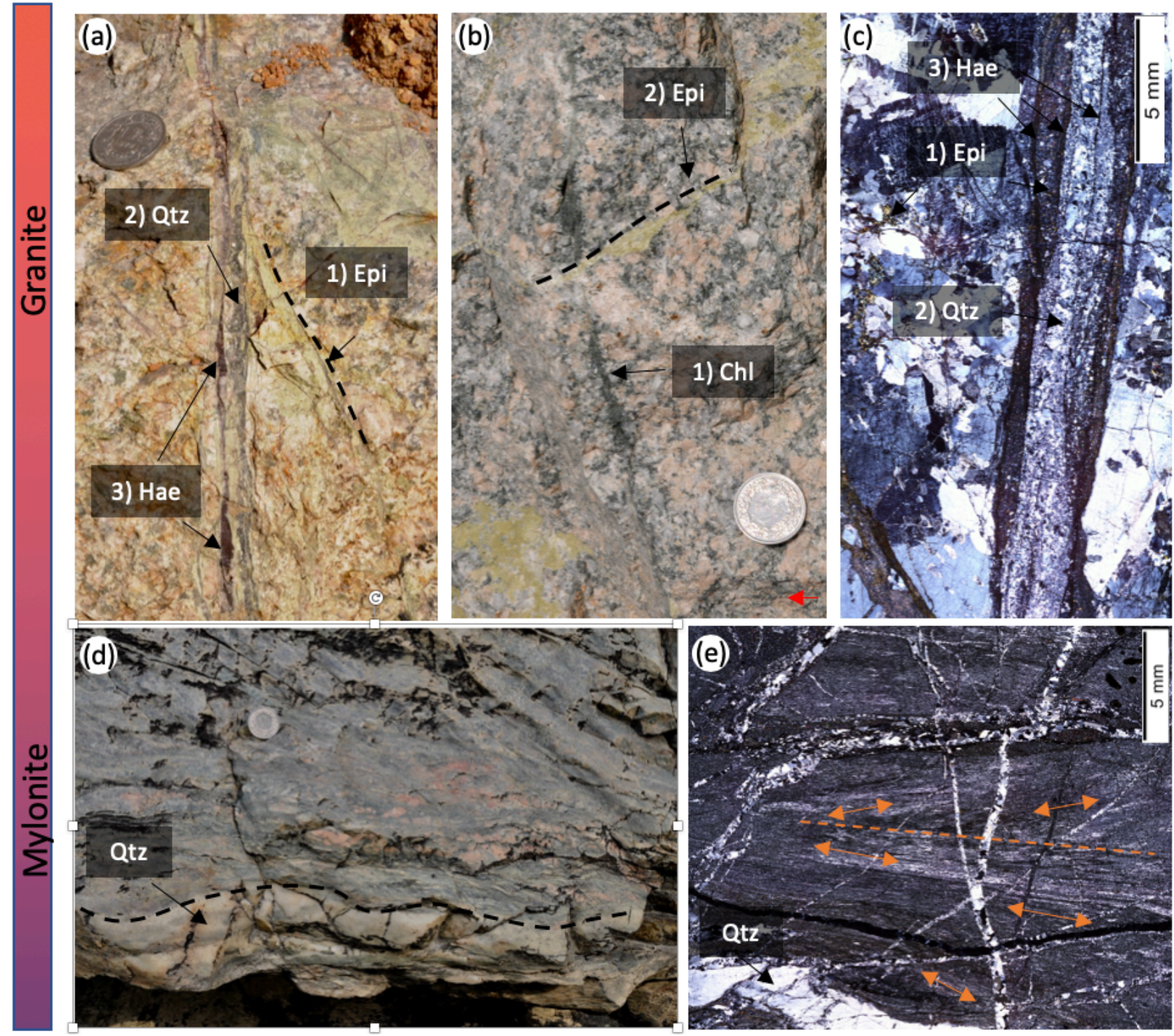

Figure 3. Macro to micro scale images of granite and mylonite from the Heyuan fault zone. Image (a) showing a footwall granite outcrop with epidote, microcrystalline quartz and haematite veining generations, (b) an adjacent outcrop with epidote cross-cutting an older chlorite vein (image way-up indicated by red arrow) and (c) a mosaic scan of a thin section taken from the same location shown under crossed polarized light. ((d) and (e) depict a branch zone of a low angled mylonite with syn- and post-mylonitisation quartz veining, in outcrop and corresponding thin section image under crossed polars displaying multiple viscous granular flow events, indicated through multidirectional foliation shown by orange arrows. (Veins abbreviations oldest to youngest: Chl-Chlorite; Epi-Epidote; Qtz-Quartz; HaeHaematite). 


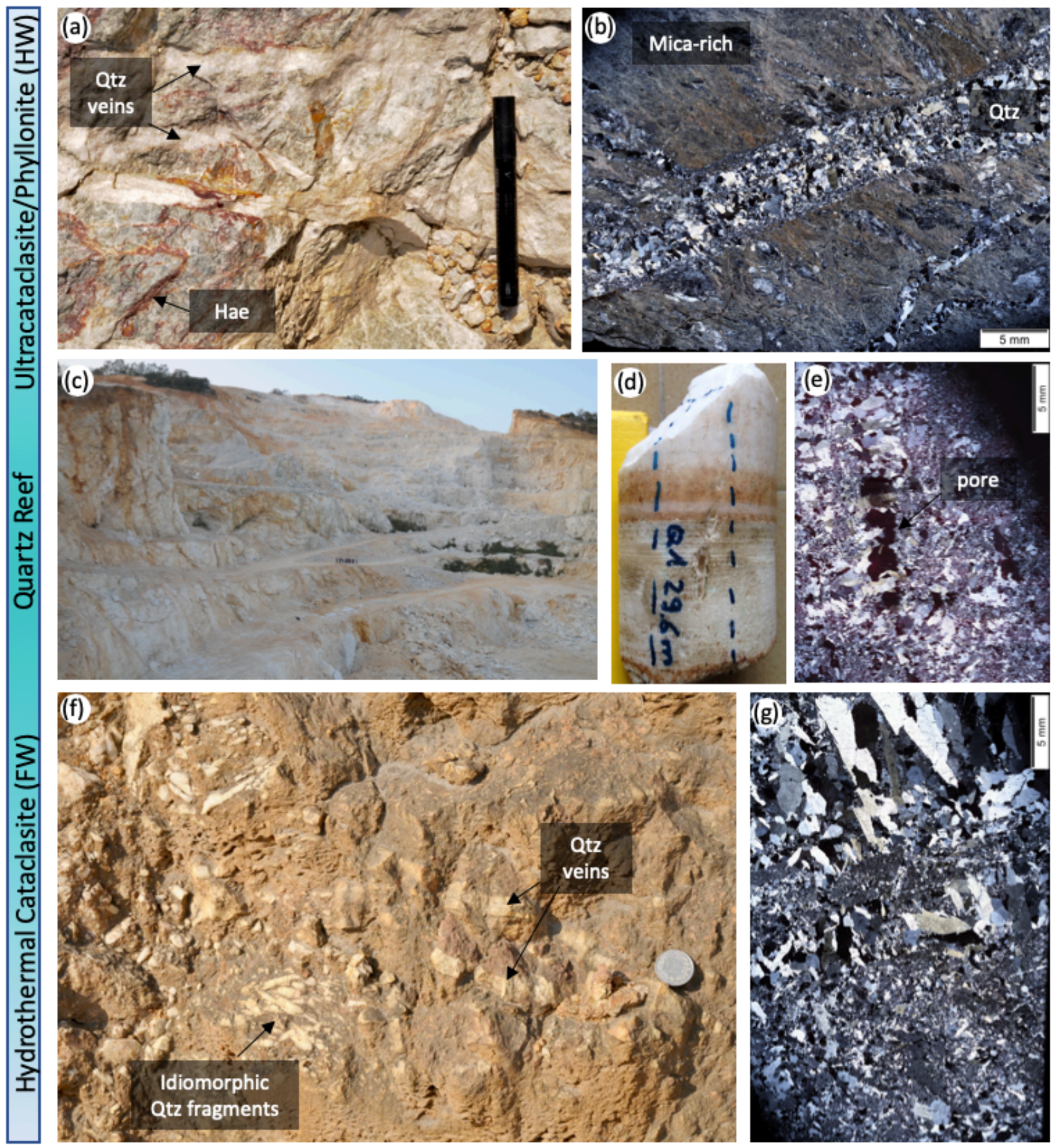

Figure 4. Macro to micro scale images of the hydrothermal cataclasite and quartz reef from the Heyuan fault zone. (a) Foliated, ultracataclasite rich in white mica (phyllonite) from the hanging wall, and (b) photomicrograph under crossed polars from the same location. Note that the rock exhibits frictional granular flow as that of a cataclasite and not a mylonite. (c) Leiyao quartz mine site where core samples are taken from $2.6 \mathrm{~m}$ through the quartz reef to the footwall cataclasite at $61.8 \mathrm{~m}$. (d) core sample from depth $29.6 \mathrm{~m}$, and (e) corresponding photomicrograph under crossed polars. (f) hydrothermal cataclasite with quartz vein fragments from the footwall of the fault, and (g) photomicrograph under crossed polars from the same location. (Veins abbreviations: Qtz-Quartz; Hae-Haematite). 

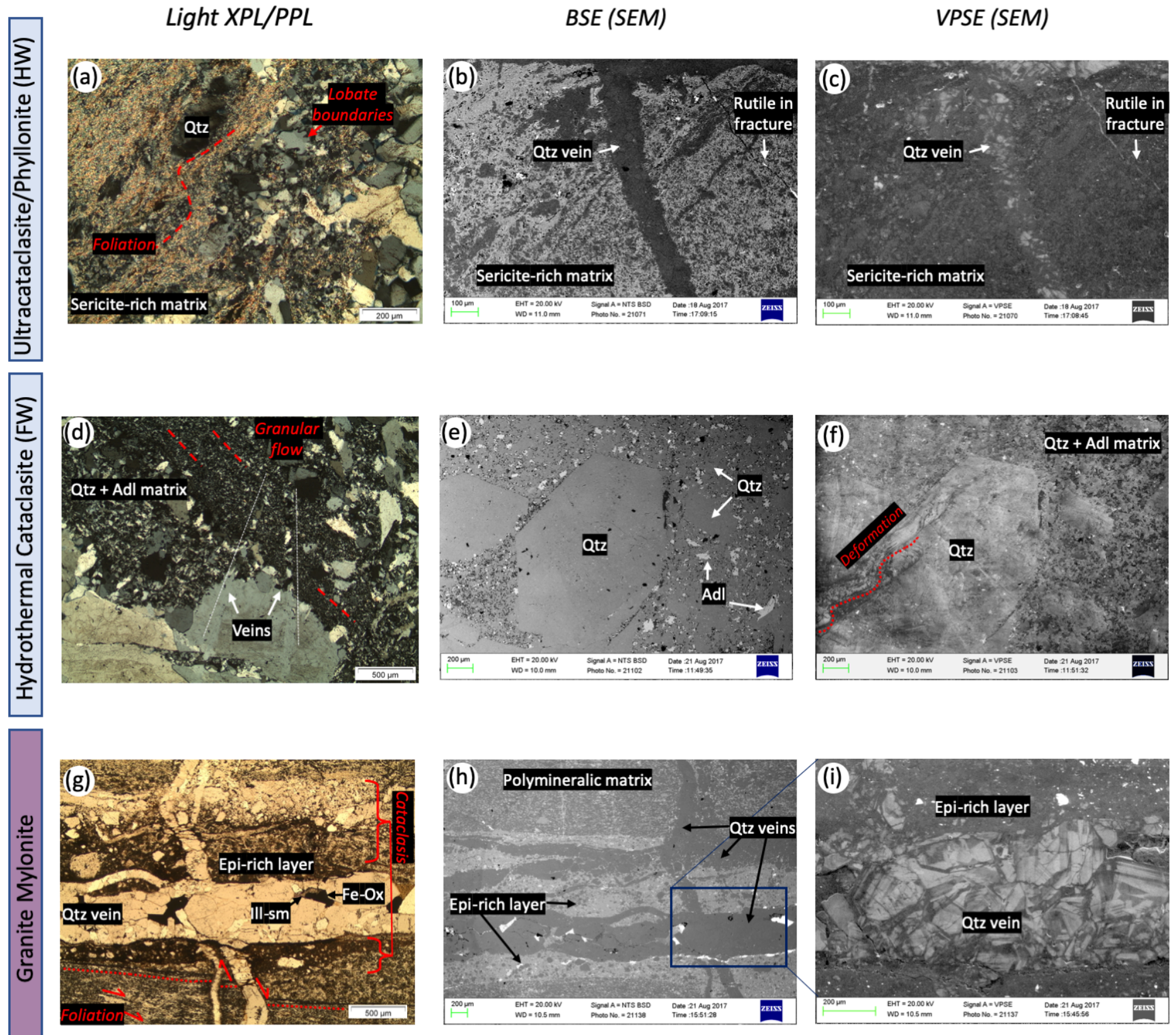

Figure 5. Microstructures in the mylonite and cataclasite facies under XPL, BSE and VPSE imaging. Note the microstructural differences between the hanging wall and footwall cataclasites (a-b) \& (d-e) where the former is foliated and mica-rich. Quartz grains with lobate boundaries are locally present in both, most obvious in (a) centre top half. (d) frictional granular flow is observed via angular grains preferentially orientated top left to bottom right across the image. (e) A fine-grained quartz-adularia matrix surrounds large euhedral quartz crystals. Adularia appears to have grown into the pore space following cataclasis and large quartz crystal growth. (f) The large euhedral quartz exhibits deformation along the crystal edge along direction of the c-axis. (g) \& (h) show the mylonite foliation, which has been injected with an epidote-rich vein that subsequently underwent cataclasis, and has been reinjected with multiple generations of quartz veins, including a high angled shear vein offsetting the mylonite and epidote veining. (i) is at higher magnification on the quartz vein from ( $\& \& h)$, (i); The high magnification VPSE image highlights the brittle overprint of later fracturing within the larger quartz vein. (Mineral abbreviations: Qtz: Quartz, Adl: Adularia, Epi: Epidote, Fe-Ox: Iron Oxide, Ill-sm: Illite-smectite clay). 
Table 1. Location of key samples in reference to depth below the fault plane. Q1 samples refer to drill core samples taken from Leiyao mine site (Fig. 2a), which traverse vertically through the quartz reef and into the cataclasite in the footwall of the fault.

\begin{tabular}{|c|c|c|}
\hline Unit & Sample & $\begin{array}{l}\text { Approx. depth below } \\
\text { fault plane (m) }\end{array}$ \\
\hline Quartz-sericite ultracataclasite/phyllonite & HY17-10 a, b, c & in fault plane \\
\hline \multirow{9}{*}{ Quartz reef } & Q1-2.6 & 2.6 \\
\hline & Q1-5.6 & 5.6 \\
\hline & Q1-12.4 & 12.4 \\
\hline & Q1-19.8 & 19.8 \\
\hline & Q1-29.6 & 29.6 \\
\hline & Q1-36.8 & 36.8 \\
\hline & Q1-41.6 & 41.6 \\
\hline & Q1-48.95 & 48.95 \\
\hline & Q1-57.6 & 57.6 \\
\hline \multirow{2}{*}{ Quartz-adularia cataclasite } & Q1-61.8 & 61.8 \\
\hline & HY17-11b & 65 \\
\hline \multirow{3}{*}{ Granite mylonite } & HY17-18 & 120 \\
\hline & HY17-8 & 200 \\
\hline & HY17-21 & 200 \\
\hline \multirow{2}{*}{ Granite Host } & HY17-5 & 250 \\
\hline & HY17-1 & 540 \\
\hline
\end{tabular}


Table 2. Vein generations across the fault zone. Chlorite and epidote-rich veining occurring pre-syn-kinematically with mylonitisation evolves towards quartz dominant veining post-mylonite formation. Vein orientation changes from moderate dipping (during chlorite and epidote phases) through low angled and finally high angled accompanying the changed from mode-I to shear formation in the quartz veining. Structural facies abbreviations: Gr-Granite; My-Mylonite; Cat-Hydrothermal Cataclasite; PhyUltracataclasite/phyllonite; FW-Footwall; HW-Hanging wall. The quartz reef is not included in the structural facies as it is not possible to distinguish individual generations of veins; other criteria have been used to evaluate the formation and generations building the quartz reef (section 6, Figure 6).

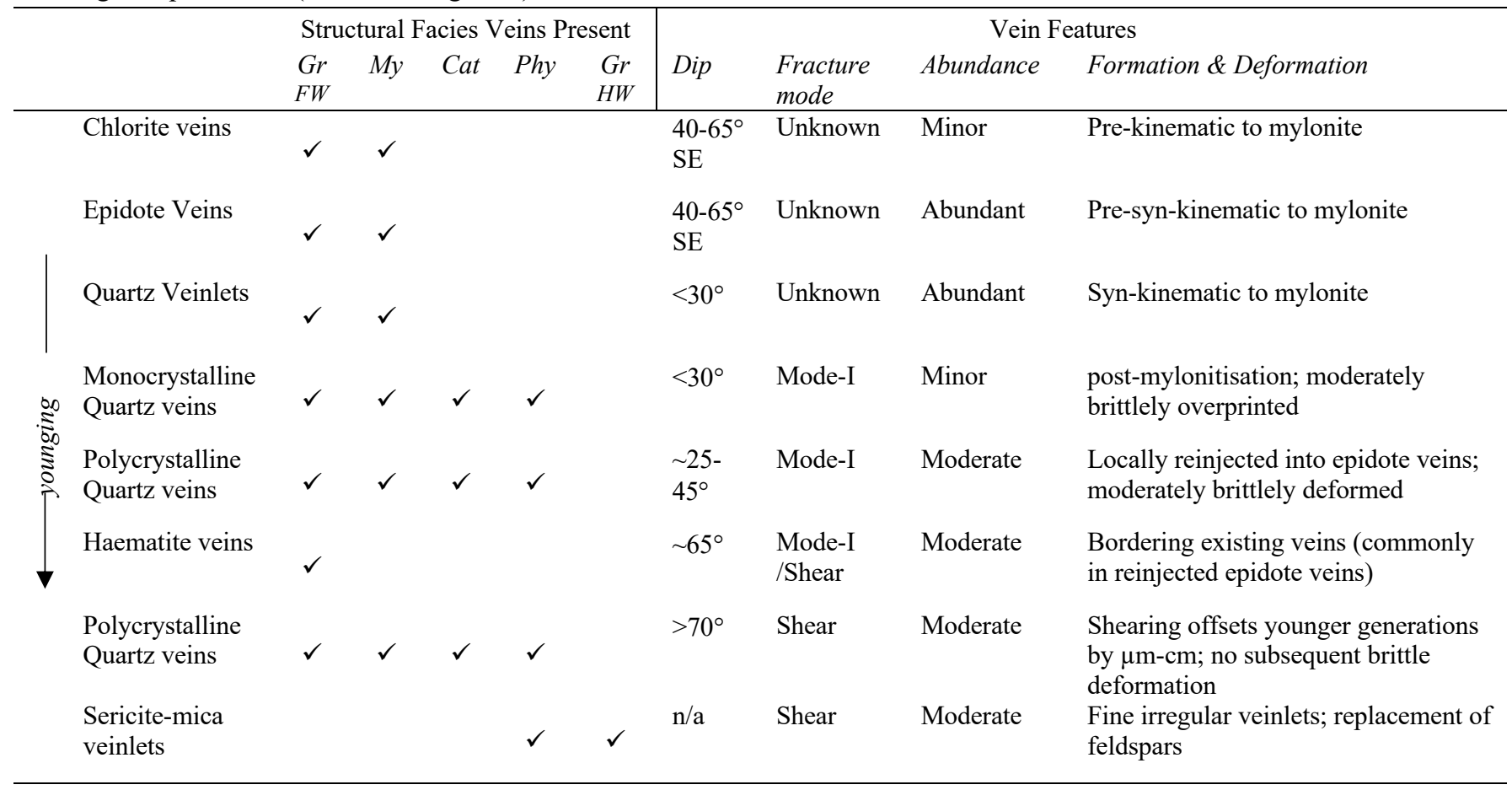




\section{Ultracataclasite/Phyllonite (HW)}

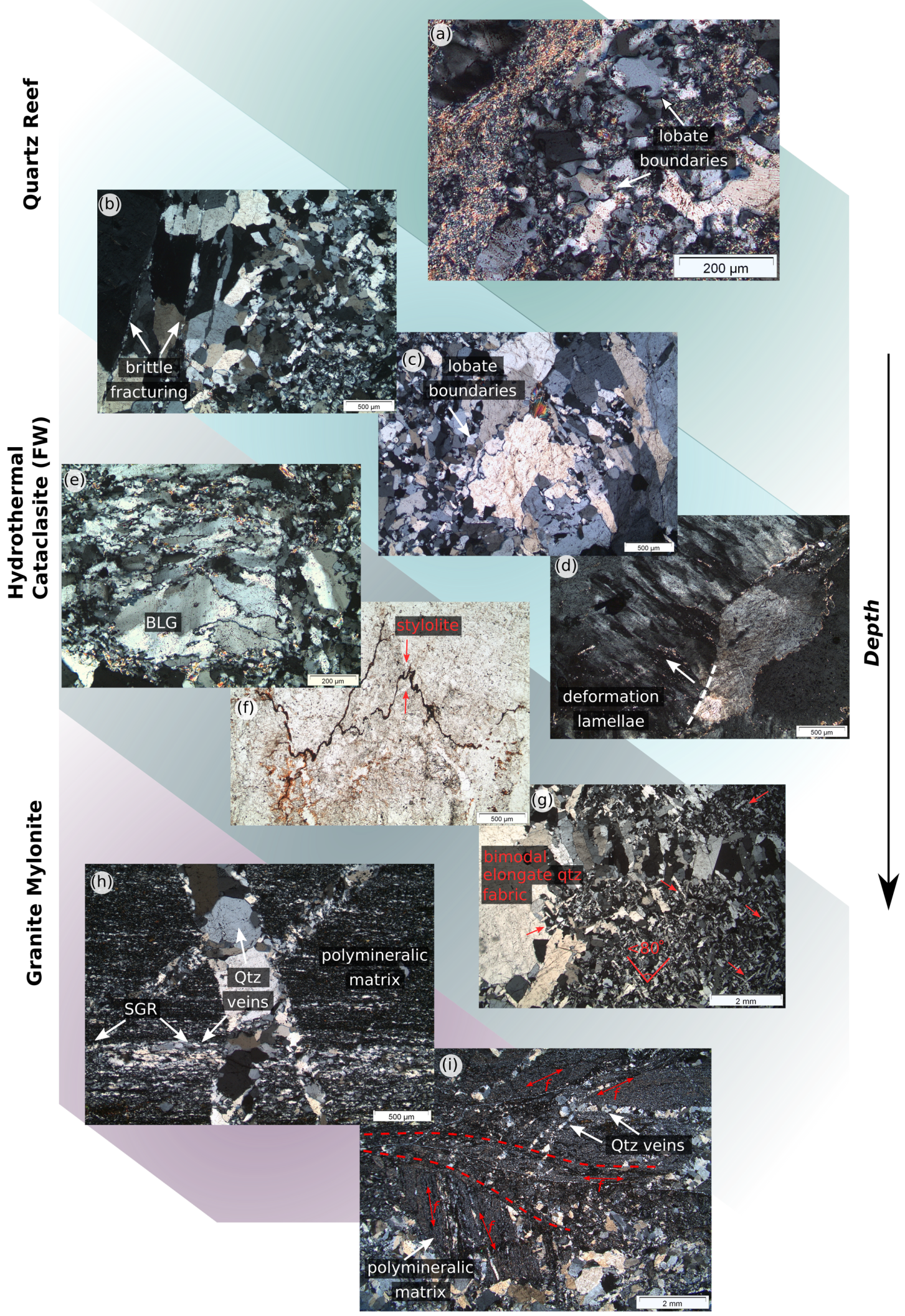

Figure 6. Deformation microstructures through the fault zone shown under transmitted light microscope. With increasing depth, the style of deformation changes; (a) locally lobate boundaries are seen in the ultracataclasite/phyllonite; (b) abundant brittle fracturing continues in the quartz reef, and (c) \& (d) pressure solution continues to increase with depth into the footwall cataclasite (f) where localised stylolites manifest. (e) Bulging Recystallisation (BLG) is locally observed in the footwall cataclasite at the boundary with the quartz reef; ( $\mathrm{g}$ ) elongate quartz grains are orientated in a bimodal pattern - possibility indicating conjugate crack-seal processes. In the mylonite (h) a quartz vein (horizonal across the bottom of the image) has undergone deformation through Subgrain Rotation Recystallisation (SGR); and (i) multiple phases of viscous granular flow are evident through cross-cutting foliation ' $f$ '. Quartz veins deformed within the matrix as wells and cross-cutting, signifying pre/syn- and post-mylonitic brittle events, which may indicate ductile-brittle cycles. Images taken under crossed polars (XPL), except image ' $\mathrm{f}$ ' which is under plane polarised light (PPL). 
Table 3. Summary of the percentage of (i) coarse, (ii) intermediate, (iii) fine and (iv) ultra-fine grain sizes in the quartz reef, and whether these are a product of 'Hydrothermal Growth Preservation' versus 'Fracture' mechanisms. * denotes grain size present $(<5 \%)$.

\begin{tabular}{|c|c|c|c|c|}
\hline \multirow{3}{*}{$\begin{array}{l}\text { Sample \# } \\
\text { (depth m) }\end{array}$} & \multicolumn{4}{|c|}{ Hydrothermal Growth Preserved } \\
\hline & \multicolumn{4}{|c|}{ Grain Size \% } \\
\hline & Coarse & Intermediate & Fine & Ultrafine \\
\hline Q1-2.6 & 60 & 15 & 25 & $*$ \\
\hline Q1-5.6 & 45 & 45 & 10 & $*$ \\
\hline Q1-12.4 & 45 & 45 & 10 & - \\
\hline Q1-19.8 & 60 & 10 & 30 & - \\
\hline Q1-29.6 & 20 & 80 & 20 & - \\
\hline Q1-36.8 & 70 & 15 & 15 & - \\
\hline Q1-41.6 & 95 & - & 5 & - \\
\hline Q1-48.95 & 60 & 20 & 20 & - \\
\hline Q1-57.6 & 95 & 5 & - & - \\
\hline Q1-61.8 (FW cataclasite) & \multicolumn{4}{|c|}{$\longleftarrow$ breccia $\longrightarrow$} \\
\hline
\end{tabular}

Table 4. Mineralogy of the quartz reef. As observed through petrographic analysis in selected samples from the drill core at Leiyao mine site. (*****: dominant $>90 \%$; $* * *$ : very abundant; $* * *$ : abundant; $* *$ : moderate; $*$ : minor; TR: trace amount).

Facies

Sample /depth (m)

Quartz

Muscovite / Phengite

Fuchsite

Clay group

Gold

Cr-oxide

Haematite

Pyrite

Ti-Oxide

Magnetite

Zircon

Apatite

Monazite
Quartz Reef

\begin{tabular}{ll}
\hline $\mathrm{Q} 1-2.6$ & $\mathrm{Q} 1-19.8$ \\
$* * * * *$ & $* * * * *$ \\
$\mathrm{Tr}$ & $*$
\end{tabular}

Q1-48.95
$* * * * *$
$*$
$*$

$\mathrm{Tr}$

$*$

*

Cataclasite (FW) Q1-61.8

****

***

$\operatorname{Tr}$

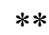

$*$

$*$

$\operatorname{Tr}$

$\mathrm{Tr}$

Tr

*

$\operatorname{Tr}$ 

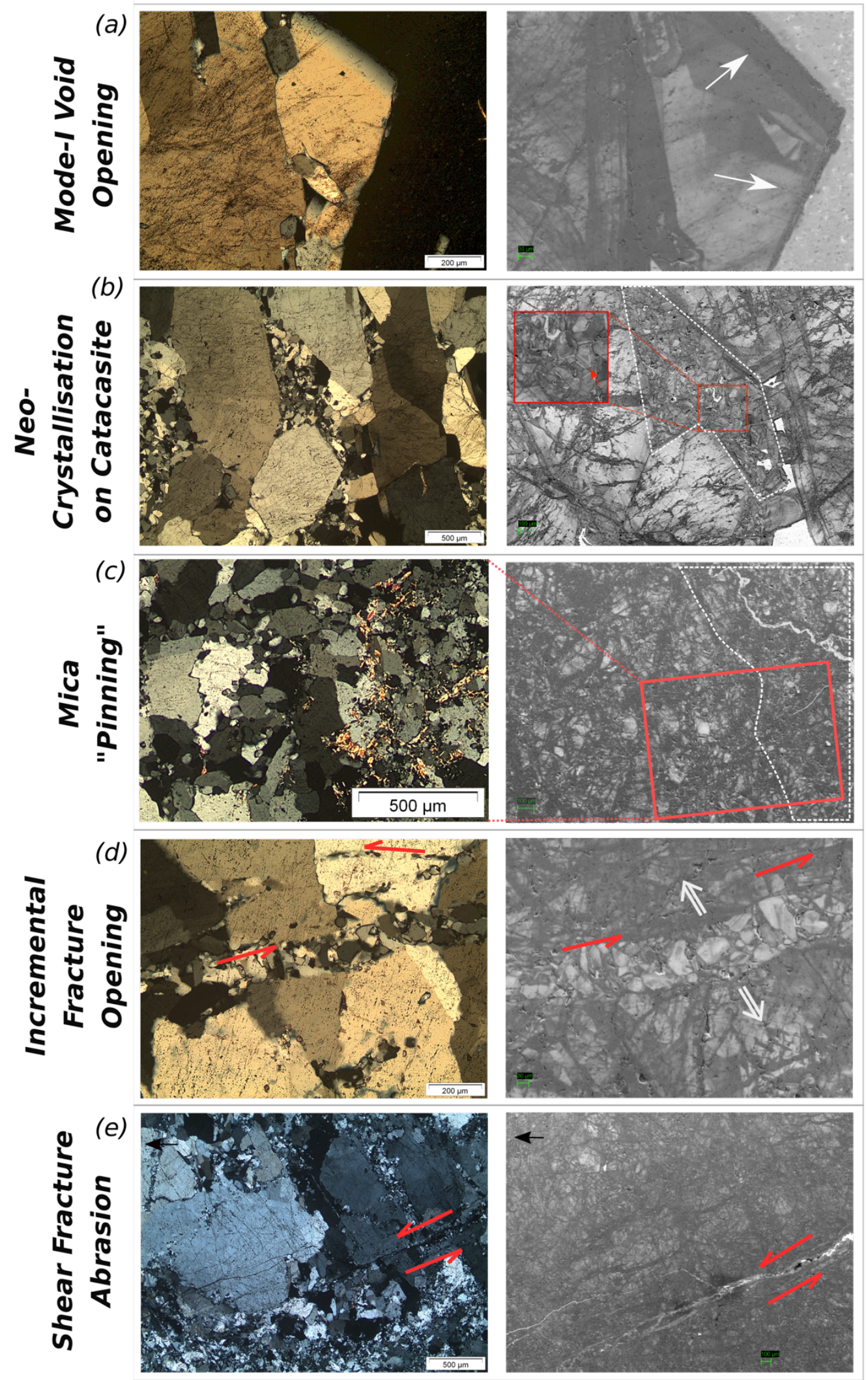

Figure 7. Grain Size Controlling Mechanisms in the Quartz Reef. These observations show the grain size in the quartz reef is correlated to one of five different formation mechanisms, which fall under the categories of "hydrothermal growth preserved', 'hydrothermal growth restricted' and 'fractured'. (Control mechanisms a, b, d, e in order of formation, while 'c' may occur at any time). There is an inverse relationship of grainsize generated with over time. (a) Large idiomorphic crystals grow into voids (indicated by arrows); (b) Neo-crystallisation occurs on previously cataclasized grains, allowing them to 'grow'; (c) mica-rich zones correlate with reduced quartz grain size (mica-rich zone highlighted in VPSE image by dashed white line); (d) crystal growth perpendicular to mode-I fracture opening (arrows denoting fracture movement), while minor shear reactivation results in repeated 'crack-seal, slip' events (Petit et al., 1999) recording incremental bands; and (e) ultra-fine, abraded quartz is deposited within shear fractures, showing no evidence of neocrystallisation (arrows denoting fracture movement). 


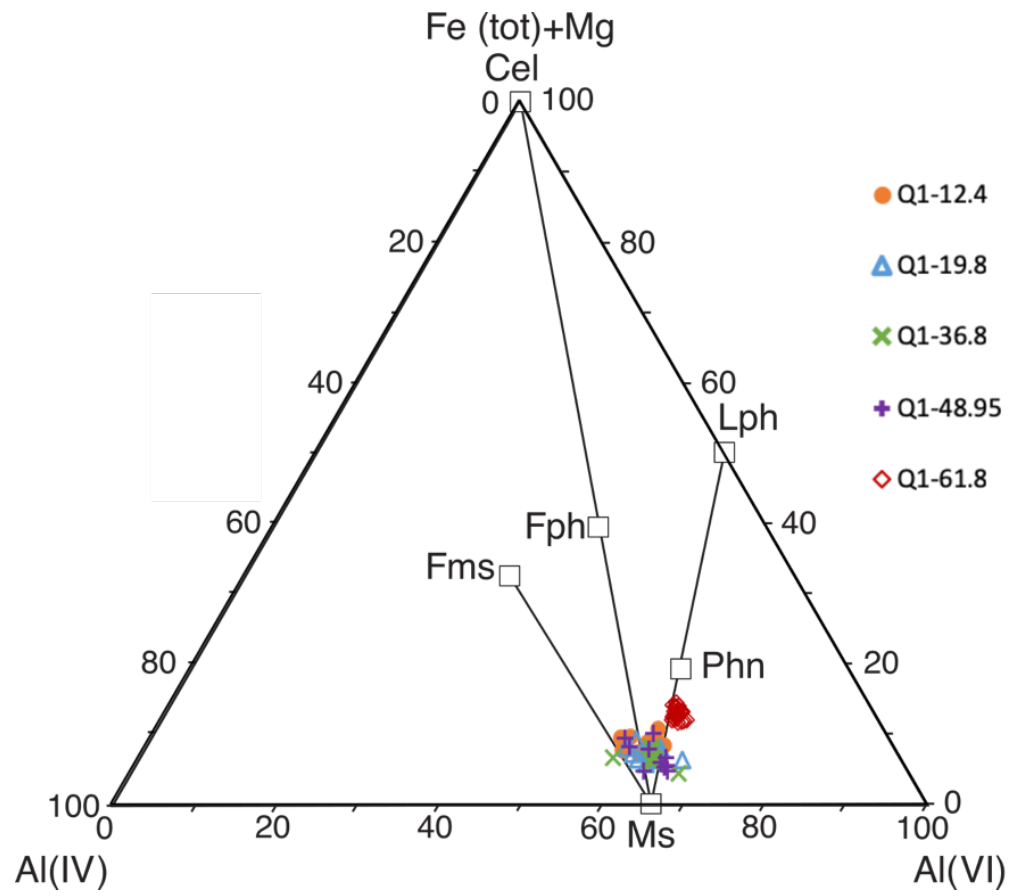

Figure 8. White mica composition in quartz reef samples (Q1-12.4, Q1-19.8, Q1-36.8, Q1-48.95) and hydrothermal cataclasite (Q1-61.8) determined from electron microprobe (EMP).

Table 5. Microprobe results of white mica and chlorite in selected samples. Temperature estimates (T) in ${ }^{\circ} \mathrm{C}$. Standard error calculated from standard deviation of the mean. $(*$ denotes analysis in which temperatures were not able to be obtained).

\begin{tabular}{|c|c|c|c|c|c|c|c|c|c|}
\hline \multirow{2}{*}{$\begin{array}{c}\text { Mineral } \\
\text { Sample } \\
\text { no. }\end{array}$} & \multicolumn{7}{|c|}{ White Mica } & \multicolumn{2}{|c|}{ Chlorite } \\
\hline & $\begin{array}{l}\text { HY17-10D } \\
\text { Phyllonite } \\
\text { (HW) }\end{array}$ & $\begin{array}{l}\text { Q1-12.4 } \\
\text { Quartz } \\
\text { Reef }\end{array}$ & $\begin{array}{l}\text { Q1-19.8 } \\
\text { Quartz } \\
\text { Reef }\end{array}$ & $\begin{array}{l}\text { Q1-36.8 } \\
\text { Quartz } \\
\text { Reef }\end{array}$ & $\begin{array}{l}\text { Q1-48.95 } \\
\text { Quartz } \\
\text { Reef }\end{array}$ & $\begin{array}{l}\text { Q1-61.8 } \\
\text { Cataclasite } \\
(\mathrm{FW})\end{array}$ & $\begin{array}{l}\text { HY17-21 } \\
\text { Granite } \\
\text { Mylonite }\end{array}$ & $\begin{array}{l}\text { HY17-1 } \\
\text { Granite }\end{array}$ & $\begin{array}{l}\text { HY17-21 } \\
\text { Granite } \\
\text { Mylonite }\end{array}$ \\
\hline $\mathrm{SiO}_{2}$ & 49.41 & 48.31 & 46.53 & 46.37 & 47.23 & 48.41 & 47.04 & 24.95 & 32.89 \\
\hline $\mathrm{TiO}_{2}$ & 0.08 & 0.08 & 0.07 & 0.05 & 0.07 & 0.06 & 0.29 & 0.03 & 0.07 \\
\hline $\mathrm{Al}_{2} \mathrm{O}_{3}$ & 29.34 & 32.76 & 33.68 & 33.91 & 33.59 & 28.35 & 27.34 & 19.57 & 20.14 \\
\hline $\mathrm{FeO}$ & 2.07 & 2.24 & 2.17 & 2.02 & 1.98 & 4.25 & 5.28 & 34.32 & 21.06 \\
\hline $\mathrm{Fe}_{2} \mathrm{O}_{3}$ & 0.00 & 0.00 & 0.00 & 0.00 & 0.00 & 0.00 & 0.00 & 0.00 & 0.00 \\
\hline $\mathrm{MnO}$ & 0.05 & 0.08 & 0.08 & 0.07 & 0.08 & 0.08 & 0.11 & 1.59 & 0.73 \\
\hline $\mathrm{MgO}$ & 0.51 & 1.15 & 1.07 & 1.11 & 0.98 & 0.63 & 0.71 & 7.87 & 7.74 \\
\hline $\mathrm{CaO}$ & 0.01 & 0.01 & 0.01 & 0.00 & 0.03 & 0.00 & 0.10 & 0.03 & 8.83 \\
\hline $\mathrm{Na}_{2} \mathrm{O}$ & 0.08 & 0.09 & 0.12 & 0.13 & 0.12 & 0.13 & 0.47 & 0.03 & 0.05 \\
\hline $\mathrm{K}_{2} \mathrm{O}$ & 10.21 & 11.05 & 11.06 & 11.13 & 10.96 & 10.85 & 10.00 & 0.03 & 0.04 \\
\hline $\mathrm{XFe}$ & 0.00 & 0.00 & 0.00 & 0.00 & 0.00 & 0.00 & 0.00 & 0.00 & 0.00 \\
\hline $\mathrm{Cr}_{2} \mathrm{O}_{3}$ & 0.00 & 0.00 & 0.00 & 0.00 & 0.90 & 0.00 & 0.00 & 0.47 & 0.30 \\
\hline Total & 91.76 & 95.77 & 94.79 & 94.79 & 95.93 & 92.77 & 91.35 & 88.89 & 91.84 \\
\hline $\begin{array}{l}T^{\circ} \mathrm{C} \\
(2 \mathrm{Kbar})\end{array}$ & $*$ & 351.2 & 372.4 & 385.3 & 347.6 & $*$ & 326.9 & 287.0 & 265.1 \\
\hline Standard & & 6.8 & 7.5 & 9.6 & 2.3 & & 0.0 & 11.3 & 5.2 \\
\hline
\end{tabular}




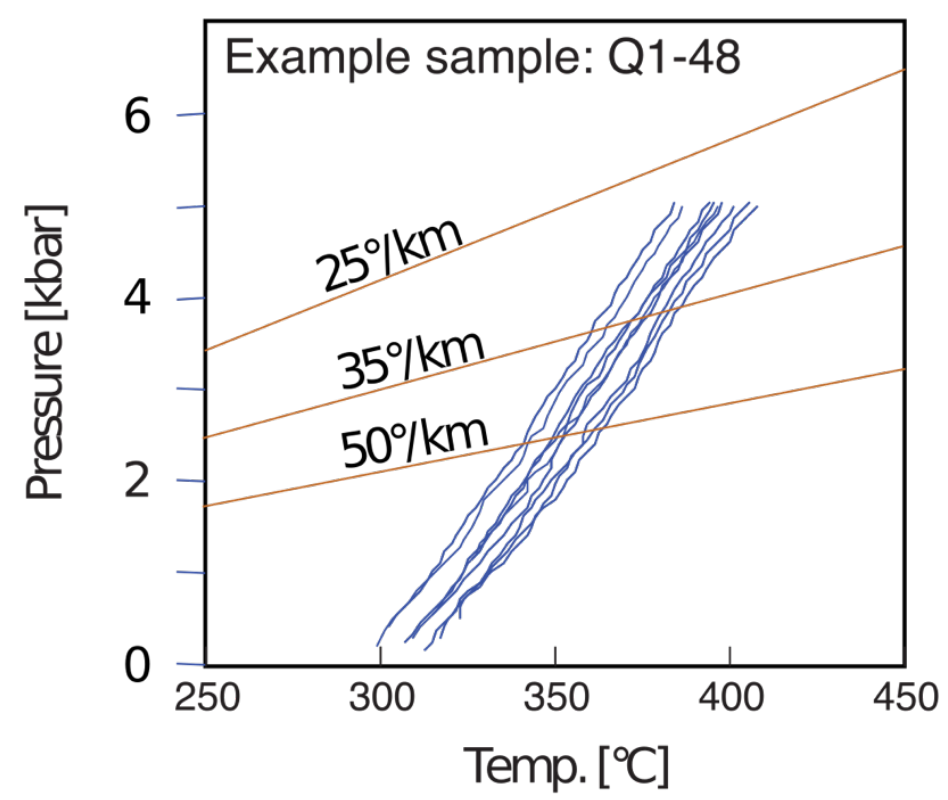

Figure 9. Temperature estimates obtained via white mica geothermometry (Dubacq et al., 2010; Lanari, 2012) for quartz reef sample Q1-48.95; blue lines representing individual analyses.

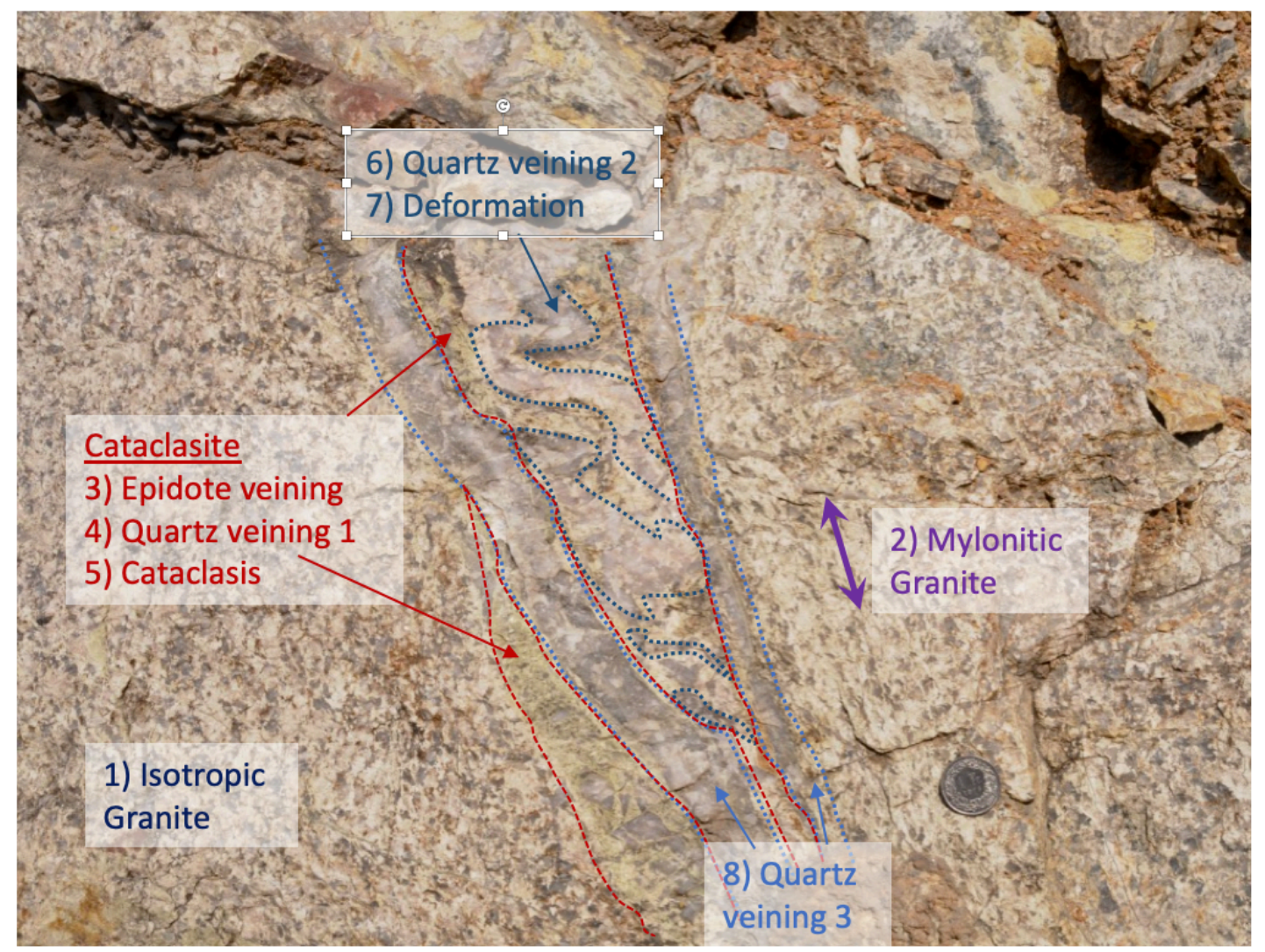

Figure 10. Multiple reactivation, injection, ductile and brittle deformation events in granite. 1) Isotropic granite undergoes 2) ductile deformation resulting in mylonitic foliation. 3) epidote-rich veins, and 4) early quartz veins within the granite are 5) later brittlely cataclasized. 6) Subsequent generations of quartz veins are injected and 7) undergo deformation. 8) Late stage quartz veins inject, cross-cutting all other features. 
Table 6. The Heyuan fault and comparable mineralized fault zones and quartz reef occurrences, and their conditions met for quartz reef formation, based on the evidence in this study.

\section{Location Tectonic setting Mineralisation \\ Fluid source \\ Temp window \\ Potential cap rock/seal}

Heyuan fault
(Guangdong,
South China)

Simplon fault
zone (Swiss Alps)

Rector Branch
thrust (North
Carolina, USA)

South Armorican
Shear Zone
Brittany, France)

Low angle
detachment fault
(changing to
compression post
QR formation)

$>40 \mathrm{~km}$ long quartz
reef, $>75 \mathrm{~m}$ wide

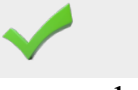

Low angle detachment fault

\section{Accumulation of quartz veins.}

Thrust fault
Dextral strike-slip
shear zone

Meteoric, with likely metamorphic, and potential deep source contributions.

Crustal metamorphic dehydration

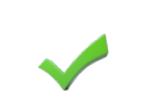

\section{Crustal metamorphic} dehydration

(1)

300 to
$500^{\circ} \mathrm{C}$

$500^{\circ} \mathrm{C}$

$<350^{\circ} \mathrm{C}$

(Lower

bounds tbc

Phyllonite seal

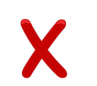

Phyllonite Seal

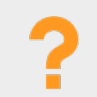

\section{0 to}

$270^{\circ} \mathrm{C}$

Unknown

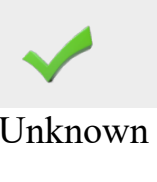

\section{2}

\section{Local veining in} phyllonite (no formation uncovered).

\section{$(300+)$ giant quartz} veins, $100 \mathrm{~m}$ to $20 \mathrm{~km}$ long (mean with 52 m). accumulation or reef

\section{Two phase vein}

formation (1) mid crustal metamorphic dehydration; (2) later meteoric recharge
Further Conditions met

(Ref).

for giant quartz reef formation? Yes

\section{(Haertel Unlikely}

and

Herwegh,

2014)

(O’Hara,

1988)

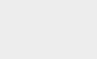
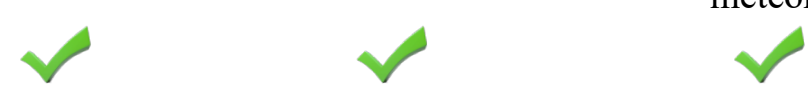


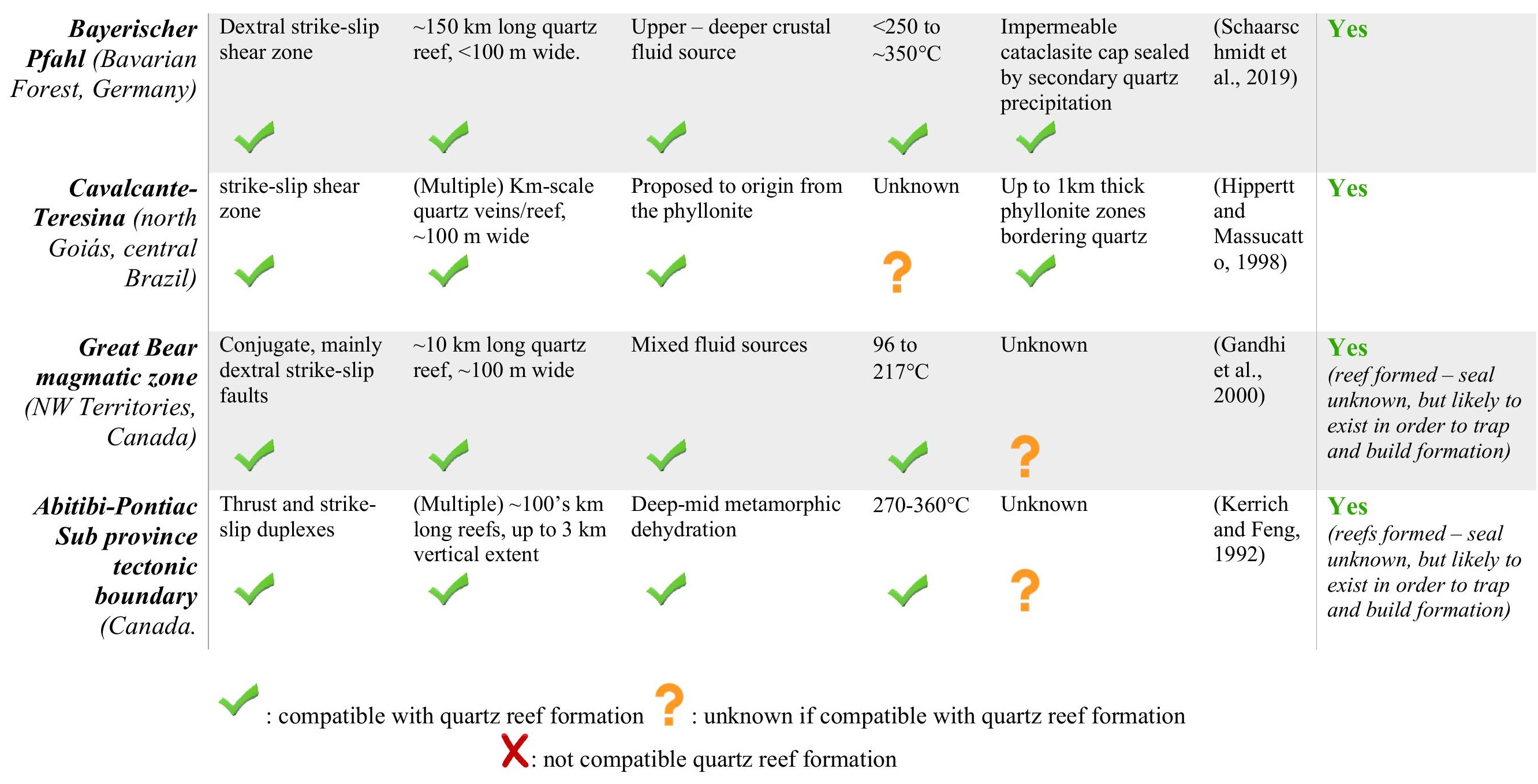




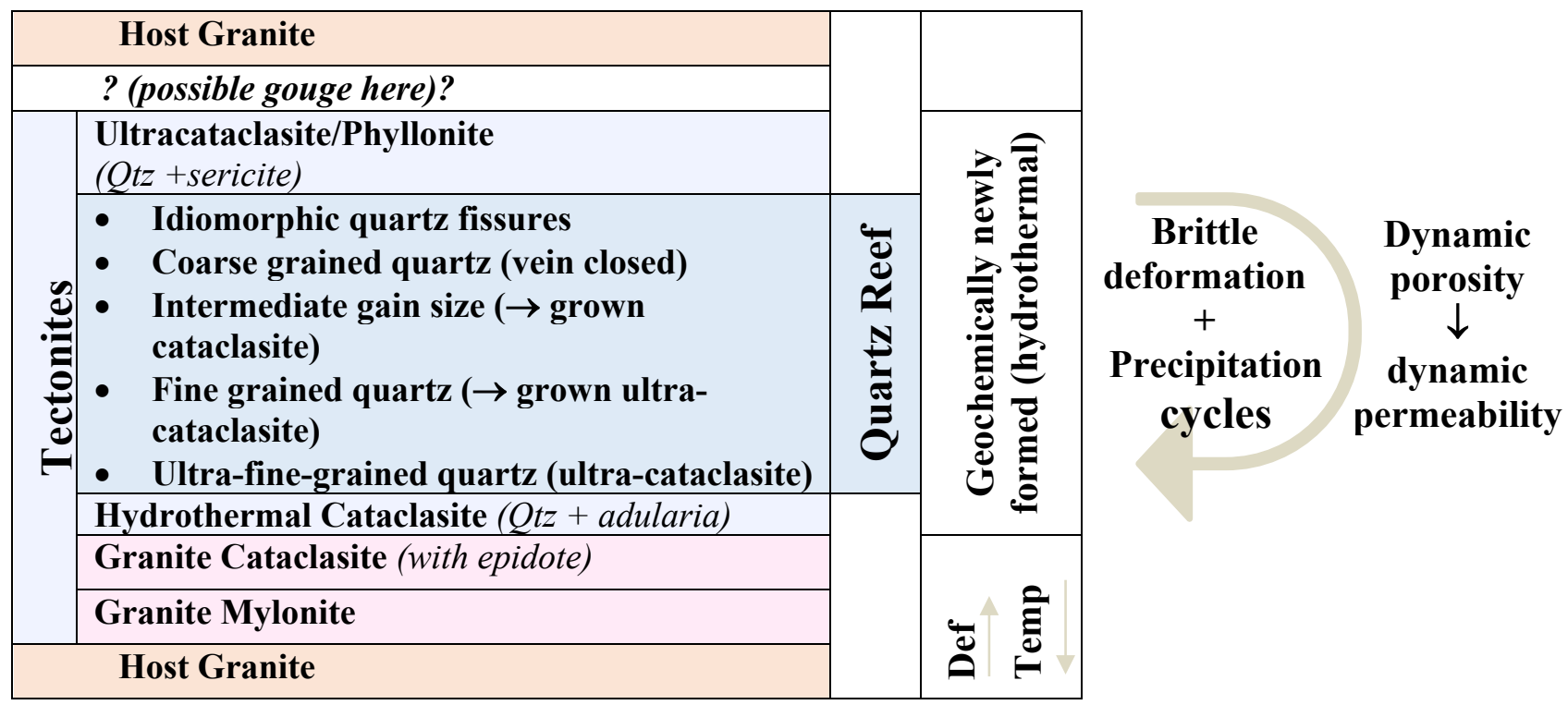

Figure 11. Fault rocks of the Heyuan fault zone and the dynamic permeability resulting from continued deformation and hydrothermal precipitation cycles.

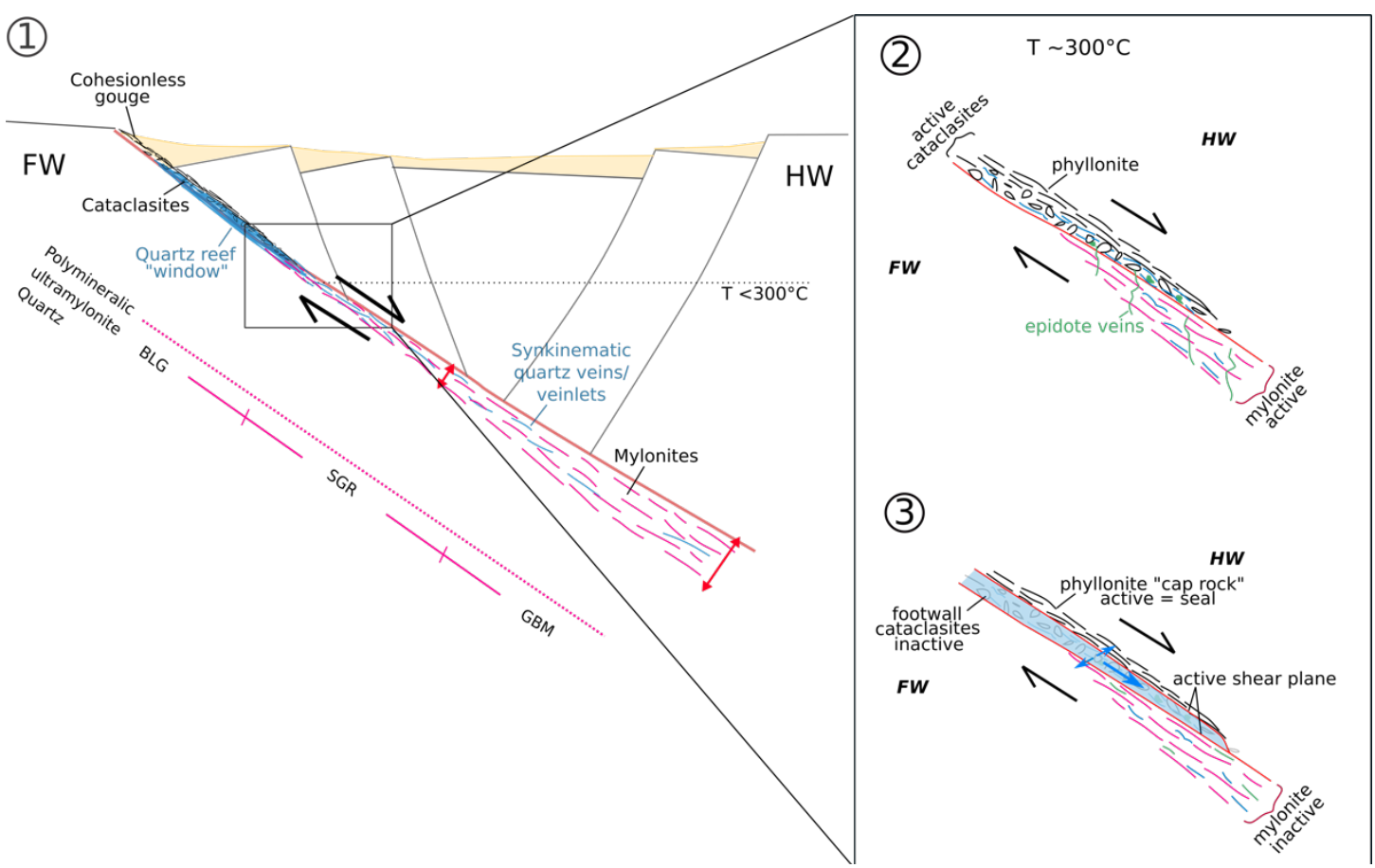

Figure 12. Schematic illustration of the processes occurring with depth through the Heyuan fault (1) and evolving through time (as shown in $2 \& 3$ for the area of interest exposed at surface today). (1) With increasing depth brittle cataclastic deformation progresses to ductile deformation at the transition from frictional to viscous granular flow; Mylonite development increases in width with depth. Quartz vein density increases towards shallower levels as the volumetric strain changes. The development of the phyllonite "cap" overlaying the cataclasite acts as a hanging wall seal to the silica-saturated fluids. (2) Continued shearing carries the cataclasties on top of the mylonite, due to the hanging wall movement relative to the footwall. Older vein generations are subsequently deformed with the mylonite. (3). The quartz reef is able to actively "grow" as the mylonite and footwall cataclasite become inactive, while the phyllonite "cap rock" remains active. 